\title{
Income Inequality in Mountain Areas: The Case of Agroforestry Farming Systems in Uluguru Mountains, Tanzania
}

\author{
Reuben M. J. Kadigi \\ Department of Food and Resource Economics, School of Agricultural Economics and Business Studies, Sokoine University of \\ Agriculture, CHUO KIKUU, Morogoro, Tanzania \\ Email:rmjkadigi@yahoo.co.uk_rmjkadigi@sua.ac.tz
}

How to cite this paper: Kadigi, R.M.J. (2021). Income Inequality in Mountain Areas: The Case of Agroforestry Farming Systems in Uluguru Mountains, Tanzania. Open Journal of Forestry, 11, 254-291.

https://doi.org/10.4236/ojf.2021.113017

Received: May 27, 2021

Accepted: July 3, 2021

Published: July 6, 2021

Copyright $\odot 2021$ by author(s) and Scientific Research Publishing Inc. This work is licensed under the Creative Commons Attribution International License (CC BY 4.0).

http://creativecommons.org/licenses/by/4.0/ (c) (i) Open Access

\begin{abstract}
Land degradation due to use of unsustainable agricultural practices has affected many communities in rural mountain areas rendering them to be more vulnerable to income poverty and inequality. In this case, agroforestry systems promise to offer great solutions as they can be developed in unfavourable conditions where other production systems would either rapidly degrade the land or otherwise would not be possible. However, little is known whether agroforestry can address issues of income inequality in mountain areas. Hence, we conducted a study to investigate the nature and determinants of income inequality in Uluguru Mountains, Tanzania. Specifically, we used the cross-sectional research design and we calculated the income percentile shares, Gini coefficients and the coefficient of variation (CV), to pinpoint the nature of income inequality in the study area. The determinants of income inequality were analysed using the step by step multiple linear model. The results of analysis suggested prevalence of income inequality. Crop production was the main source of income in the agroforestry systems of the study area. Earnings from crops and timber were decreasing income-inequality amongst smallholder farmers. Our disaggregated analysis showed that offfarm income was also decreasing income-inequality for farmers with farmlands located close to homestead, for female-headed households, for farmers who did not access extension services, and those who were members of community-based financial institutions. Estimated incomes increased with household assets, size of farmland, and age of household head. However, the same decreased with household size. We found gender disparity to be one of the key issues that need attention in formulating future policies to reduce inequality. We recommend promotion of livelihood diversification as well as the designing and implementation of tailor-made training and farm financing
\end{abstract}


mechanism to help the less resource-endowed farmers in mountain areas to raise their economic portfolios and social status and combat income poverty and inequality.

\section{Keywords}

Uluguru Mountains, Mountain Areas, Income Inequality, Income Percentile Shares, Coefficient of Variation, Step by Step Multiple Linear Regression

\section{Introduction}

Land degradation due to use of unsustainable agricultural practices has affected many communities in rural mountain areas. The available evidence from the study by Salvati (2014) for example, shows that rural communities in inland, mountainous districts of Italy were particularly exposed to the extensive phenomena of land degradation and abandonment caused by bourgeoning human populations. Elsewhere, in the Bolivian mountain valley of north Chuquisaca, the study by Kessler and Stroosnijder (2006) also provides similar evidence of soil degradation which caused dwindling availability of water and nutrient resources. They stressed the need for urgent integrated action with regard to soil and water conservation. More interesting is perhaps the argument that population growth in mountain areas can lead to land degradation or enhancement or aspects of all (Templeton \& Scherr, 1996). In their paper, Templeton and Scherr (1996) conclude that increases in the labour-land endowment ratios of households and local land demand and labour supply increase the opportunity cost of land relative to labour, consequently, people use mountainous land resources more intensively for production and consumption, thus tending to deplete resources and significantly alter habitats. Yet, capital- and labour-intensive methods of replenishing or improving soil productivity may become economically more important and attractive, especially when production systems promise greater returns than that from the systems which degrade the land (ibid). Agroforestry is one of these systems. It entails a range of land-use and farming systems which involve the deliberate growing of woody perennials (trees, shrubs, palms, etc.) on the same land-management units as agricultural crops and or animals, in some form of spatial arrangement or temporal sequence (Reyes et al., 2005; Sharma et al., 2017). Agroforestry has huge potential to control land degrading and reduce vulnerability to poverty in mountain areas. It can help rural farmers in these areas to diversify and sustain production for increased social, economic and environmental benefits. In particular, agroforestry is crucial to smallholder farmers in mountain areas because it can enhance their food supply, income and health (FAO, 2013).

Agroforestry systems offer great solutions as they can be developed in unfavourable conditions where production would either rapidly degrade the land or otherwise would not be possible (Masebo \& Menamo, 2016). They have the po- 
tential to mitigate land degradation problems through both the service and production functions played by the different components of agroforestry. They can check soil erosion to some extent, increase soil fertility, reduce salinity; alkalinity, acidity, and desertification, ultimately improve soil health which keeps the land suitable for the sustainable production of diversified products (Sharma et al., 2017). According to Sharma et al. (2017), agroforestry-related practices, such as, the use of multi-purpose tree species, relay-cropping, terracing and contour cultivation, soil and stone bunds, strip as well as alley cropping are appropriate to fulfil the needs of low-resource farmers by restoring and increasing land productivity (Sharma et al., 2017). In fact, the mainstream literature on mountainous agroforestry farming systems tends to support the assertion that agroforestry could ameliorate the living conditions of the local population and protect the natural reserves from human disturbance (Reyes et al., 2005; Kirui, 2016). Elsewhere in Tanzania, in the East Usambara Mountains, the study by Reyes et al. (2005) for example, indicated that the households who practiced improved agroforestry systems obtained twice as much annual gross income compared with their counterpart farmers who used traditional practices. They also found that about $40 \%$ of farmers who practiced improved agroforestry were securing enough food throughout the year, compared with only $18 \%$ for farmers who used traditional practices.

However, empirical evidence which shows the effect of agroforestry farming systems on poverty and income inequality is lacking, at least in the context of mountain areas. The evidence would help policy-makers and other stakeholders to formulate suitable policies, plans and strategies to achieve sustainable development in these areas. It should be noted here that, the levels of income-inequality in mountain areas may vary significantly between farming households, farmland locations and farmers' economic characteristics. To the best of our understanding, these characteristics have not yet received adequate attention among scholars as most studies attempted to evaluate income inequality in mountain areas did not consider these. In addition, studies which disaggregate inequality based on differences in household and farm characteristics such as, farmland location, gender, and access to extension, as well as membership to community-based financial institutions, like the Savings and Credit Co-operative Society (SACOS) and Village Community Bank (VICOBA), are lacking. Equally important, much of the previous research on inequality uses time series or panel data focusing on broader scales, such as national, regional and multinational levels (e.g. Kata \& Wosiek, 2020; Jaitiang et al., 2021). Studies which use crosssectional data while focusing on small scale sites and locations such as, hamlets, villages and wards of mountain areas are lacking. Where the cross-sectional data is applied, most researchers (e.g. Abebe, 2020; Ullah et al., 2020) have ignored the effects of variation in household personal characteristics, farming characteristics, economic characteristics as well as the existing transforming structures and processes. In the Karakoram valleys of Pakistan, for example, Ullah et al. 
(2020) investigated the nexus between financial inclusion and improvement in the living standards of mountain people, and reduction in economic poverty, multidimensional poverty and income inequality using the Quasi Experimental Designs, Foster, Greer and Thorbecke poverty measures, Alkire et al. methodology, Gini Index and Quintile technique. In addition, they used a Logistic Regression technique to identify the major drivers of economic poverty, multidimensional poverty and income inequality using non-disaggregated (pooled) crosssectional data. They found a positive synergy among inclusive finance and living standards and a negative connection between financial inclusion and economic poverty, multidimensional poverty as well as income inequality. Their results of logistic regression showed that financial inclusion was a potential determinant of economic poverty reduction though it was found to be an insignificant tool for eradicating multidimensional poverty.

In Poland, Kata and Wosiek (2020) used time series data covering a period of 2004-2018 to investigate the redistributive effects of agricultural policy and the importance of income inequalities among agricultural holdings for sustainable agricultural development. They used the process of concentration of production factors in this sector, as well as, the level of budget support using pooled data. Specifically, they applied the Gini coefficient, concentration index, and multivariate regression analysis to establish a relationship between the processes of income polarization in agriculture and the process of concentration of production factor as well as the level of budget support. They found that the process of the concentration of land and capital led to an increase in income inequalities and the budgetary expenditure directed to the sector (in the form of subsidies supporting farmer incomes) was not able to reverse the process of income polarization, but mitigated the growing inequalities by reducing the scale of income spreads.

In the Mueang District area of Nan Province in Northern Thailand, Jaitiang et al. (2021) have investigated inequalities in the distribution of estimated income among urban farmers using the Lorenz curves and Gini indices. They used regional raw data which had an intricate design and construct gathered during a survey that was conducted annually by the Department of Agricultural Extension in Thailand. They estimated farmers' incomes and identified the determinants of farm income diversification in each sub-district using the Tobit model. Their results showed that urban farmers had high inequality scores, and there was a wide range of income inequality among farmers. They found ownership, land entitlement, and farmland size to be positively influencing farmers' estimated income. Rice farming was significantly raising income disparity, while maize cultivation was negatively affected. El Benni and Finger (2013) used time series and panel data to analyse the development of income inequality in Swiss agriculture for the valley, hill and mountain regions using time series data for the period 1990-2009. Their results show that, while household income inequality remained stable, farm income inequality increased during this period. Their 
estimates of Gini elasticities suggested that household income inequality was reduced by off-farm income and direct payments but it was increased by market income. They recommend that agricultural policies should opt for measures that comply with regional requirements, as current direct payments cannot avoid income inequality among farmers.

As such, rigorous studies that investigate the nature and causes of income inequality in mountain areas by considering the variations in personal characteristics, farming characteristics and some key transforming structures remain an important gap in the literature, which we address in this paper using the case of Uluguru Mountain in Tanzania. Specifically, we use the cross-sectional research design, income percentile shares, Gini coefficient and Lorenz curves, as well as, the coefficient of variation (CV), to investigate the nature of income inequality in the study area using both pooled and disaggregated data. We estimate farmers' income by applying the step by step multiple linear regression which helps to determine the factors that influenced income inequality in the study area.

\section{Theoretical and Conceptual Frameworks}

\subsection{Theoretical Framework}

The studies of unequal distribution of income or income inequality among different sections or groups of the society are mainly guided by two principal theories namely; the theory of personal or size distribution of income and the theory of functional or distributive factor share distribution of income (Bastos et al., 2009; Todaro \& Smith, 2012). The first theory (theory of personal or size distribution of income) is the most commonly used by income inequality analysts. It simply deals with individual persons or households and the total incomes they receive. Often, the way in which that income was received is not considered (ibid). What matters in this regard is how much each earns irrespective of whether the income was derived solely from a single source or came also from other sources income (Todaro \& Smith, 2012). Economists and statisticians therefore, like to arrange all individuals by ascending personal incomes and then divide the total population into distinct groups, or sizes. A common method is to divide the population into successive quintiles (fifths) or deciles (tenths) according to ascending income levels and then determine what proportion of the total income is received by each income group. In this case, income inequality is commonly measured as the ratio of the incomes received by the top $20 \%$ and bottom $40 \%$ of the population. This ratio is sometimes dubbed a Kuznets ratio, after the Nobel laureate Simon Kuznets. It has often been used as a measure of the degree of inequality between high- and low-income groups. Another common way to analyse personal income statistics is to construct a Lorenz curve (i.e. a graph depicting the variance of the size distribution of income from perfect equality). The Gini coefficient or Gini index $(G)$ is another commonly used measure of the relative degree of income inequality (Ahearn et al., 1985; Adams, 
1994; Keeney, 2000; Fang \& Rizzo, 2011; Li et al., 2011; Ciliberti \& Frascarelli, 2018; Jaitiang et al., 2021). There are various formulas that are used to calculate the Gini coefficient. An example of these is presented in Equation (1) (Jaitiang et al., 2021).

$$
G=\frac{1}{2 n^{2} \bar{y}} \sum_{i=1}^{n} \sum_{j=1}^{n}\left|y_{i}-y_{j}\right|
$$

where, $i$ represents the unit within a population of size $n, y$ represents the farm income of a farmer, and $j$ is the total sum index.

The difference between Gini index $(G)$ and Gini coefficient needs to be noted here. The former $(G)$, is the Gini coefficient expressed as a percentage, and is equal to the Gini coefficient multiplied by 100 . The Gini coefficient is equal to half of the relative mean difference. In the context of the Lorenz curve diagram, the Gini coefficient is defined as a ratio of the areas on this diagram. If the area between the line of perfect equality and Lorenz curve is $A$, and the area under the Lorenz curve is $B$, then the Gini coefficient is $A /(A+B)$. Since $A+B=0.5$, the Gini coefficient, $G=2 A=1-2 B$. Gini is therefore defined as the arithmetic mean of the absolute values of differences between all pairs of incomes and it can also be expressed as in Equation (2) (Sen, 1997).

$$
G=1+\left(\frac{1}{n}\right)+\left(\frac{2}{n^{2} \mu}\right)\left[y_{1}+2 y_{2}+\cdots+n y_{n}\right]
$$

for $y_{1} \geq y_{2} \geq \cdots \geq y_{n}$, where $\mu$ is the mean income. McDonald et al. (2005), following Stuart (1954) define the Gini coefficient in terms of covariances as expressed in Equation (3).

$$
G=\frac{2 \operatorname{cov}(y, F(y))}{\mu}
$$

where, $y$ and $\mu$ are as defined in the previous equations, and $F(y)$ is the cumulative density function of income.

Other approaches related to linearization methods for estimating the standard error of the Gini estimator are based on the influence function of the Gini index (Cowell \& Victoria-Feser, 2003; Langel \& Tillé, 2013; Giorgi \& Gigliarano, 2017) and on estimating equations (Kovacevic \& Yung, 1997). Linearization techniques are aimed to obtain the asymptotic distribution of the Gini index (Hoeffding, 1992). Alternatively, estimation of the variance of the Gini coefficient can be based on re-sampling methods, such as the bootstrap technique (Mills \& Zandvakili, 1997; Biewen, 2000; Palmitesta et al., 2000; Biewen; 2002). Most of these papers recommend the use of bootstrap rather than the asymptotic methods especially in applications where the sample size is not large. Several authors have also recommended the use of JRR technique to estimate a standard error for the Gini coefficient. By applying the JRR approach, it is possible to get less biased estimates than those obtained with traditional methods (Schechtman, 1991; Yitzhaki, 1991; Ogwang, 2000; Giorgi \& Gigliarano, 2017). The use of Gini decomposition together with the concentration curve is also becoming popular in in- 
come-inequality studies. For example, a recent work by Nitta et al. (2020) uses Gini decomposition and concentration curve to investigate the income-equalizing effect of direct payments on rice income in Japan. The study indicates that the direct payments in Japan were highly concentrated but they nevertheless reduced rice income inequality. The findings also show that the equalizing effect of direct payments was less than that in other countries because the Japanese payments were linked to participation in an acreage reduction program and were not fully decoupled. To pursue greater income equality, the study by Nitta et al. (2020) recommend policymakers to decouple the payments and introduce mechanisms to decrease or limit the amount of support to the largest beneficiaries.

The Coefficient of variation $(\mathrm{CV})$ of incomes is also widely used as a measure of the degree of income inequality. It is one of the statistical parameters that measure the diversification of characteristics distribution, which, in contrast to the standard deviation (determining the non-relative diversification of a characteristic), is a relative measure, dependent upon the arithmetic mean value (Bedeian \& Mossholder, 2000). The variance of a stochastic variable is estimated using the deviation from the mean. Instead of using the absolute differences, these deviations are squared. This has the result of accentuating the deviations that are further away from the mean (Sen, 1997). The standard deviation is simply defined as the square root of the variance. The latter can be estimated using the following formula given in Equation (4):

$$
V=\frac{1}{n} \sum_{i=1}^{n}\left(y_{i}-\mu\right)^{2}
$$

From an inequality analysis point of view, an attractive feature of the variance (or standard deviation) is that any transfer from a poorer person to a richer person, ceteris paribus, will increase the variance and hence the inequality, thus satisfying the Pigou-Dalton principle for inequality measures (Sen, 1997). However, the variance depends on the mean income, and one distribution may show a greater relative variation but have a lower variance if it has a smaller mean. The variance is also not independent of the income scale. If all incomes are doubled, the variance quadruples, thus violating the income scale independence axiom. This is perhaps an "undesirable property" (see Litchfield, 1999). CV counters this problem by concentrating on the relative variation. It is simply defined as the standard deviation divided by the mean (Equation (5)). This inequality measure is a member of the Generalised Entropy measures. CV has the property that it attaches equal weights to transfers at different levels of income. If a household with income $y$ transfers some of its income to another with income $(y-d)$, the impact is the same whatever the level of $y$ (Sen, 1997).

$$
\mathrm{CV}=\frac{\sqrt{V}}{\mu}
$$

The second theory, theory of functional or factor share distribution of income, attempts to explain the share of total national income that each of the factors of 
production (land, labour, and capital) receives (Francese \& Mulas-Granados, 2015). Instead of looking at individuals as separate entities, the theory of functional income distribution makes reference to the percentage that labour receives as a whole and compares this with the percentages of total income distributed in the form of rent, interest, and profit (i.e., the returns to land and financial and physical capital) (ibid). Although specific individuals may receive income from all these sources, that is not a matter of concern for the functional approach (ibid). The theory attempts to explain the income of a factor of production by the contribution that this factor makes to production assuming that supply and demand curves determine the unit prices of each productive factor. When these unit prices are multiplied by quantities employed on the assumption of efficient (minimum-cost) factor utilization, then a measure of the total payment to each factor is obtained. For example, the supply of and demand for labour are assumed to determine its market wage. When this wage is multiplied by the total level of employment, a measure of total wage payments, also sometimes called the total wage bill, is obtained. It is a neat and logical theory in that each and every factor gets paid only in accordance with what it contributes to national output, no more and no less. This model of income distribution is at the core of the Lewis theory of modern-sector growth based on the reinvestment of rising capitalist profits (Pélabon et al., 2020). Unfortunately, the relevance of the functional theory is greatly diminished by its failure to take into account the important role and influence of nonmarket forces such as power in determining these factor prices (Park et al., 2021).

In general, new approaches are emerging to make the results of income inequality analysis more meaningful. Park et al. (2021) for example, have proposed a new framework for measuring income inequality based on the unequally distributed (UD) incomes that are obtained by removing the equally distributed parts from incomes. They then derive the normalized norm indexes from the cumulative distribution function and the un-scaled Lorenz curve of the UD incomes. Using the example of income distributions and the Luxembourg Income Study datasets, Park et al. (2021) show that, the normalized norm indexes evaluated income inequality appropriately and solved the negative income problem. Elsewhere in the Mediterranean countries, Benedetti et al. (2020) provide point and variance estimates of two widely used income-poverty indicators, belonging to the class of the Foster-Greer-Thorbecke (FGT), and two widely used incomeinequality indicators. They analyse the spatial distribution of poverty by constructing maps at territorial level. Their estimation results revealed that national poverty indicators hide a high heterogeneity of poverty across regions within each country. They adopted the Jackknife replication method because of its convenient properties and they found that the uncertainty measure was influenced by the reduced number of sampling units in each region. It should be noted here that, the FGT class is preferred by some researchers for having certain advantages, including its simple structure based on powers of normalized shortfalls, which facilitate communication with policymakers (Foster et al., 2010). 
Its axiomatic properties are also viewed as sound and include the helpful properties of additive decomposability and subgroup consistency, which allow poverty to be evaluated across population subgroups in a coherent way (ibid).

\subsection{Conceptual Framework}

We constructed a conceptual framework (Figure 1) which shows that income inequality and poverty in mountain areas, is a result of an array of both internal and external factors. These factors vary depending on the nature and source of inequality, such as, inequality in earnings of the working population, inequality in earnings of the total population, as well as, household income inequality before

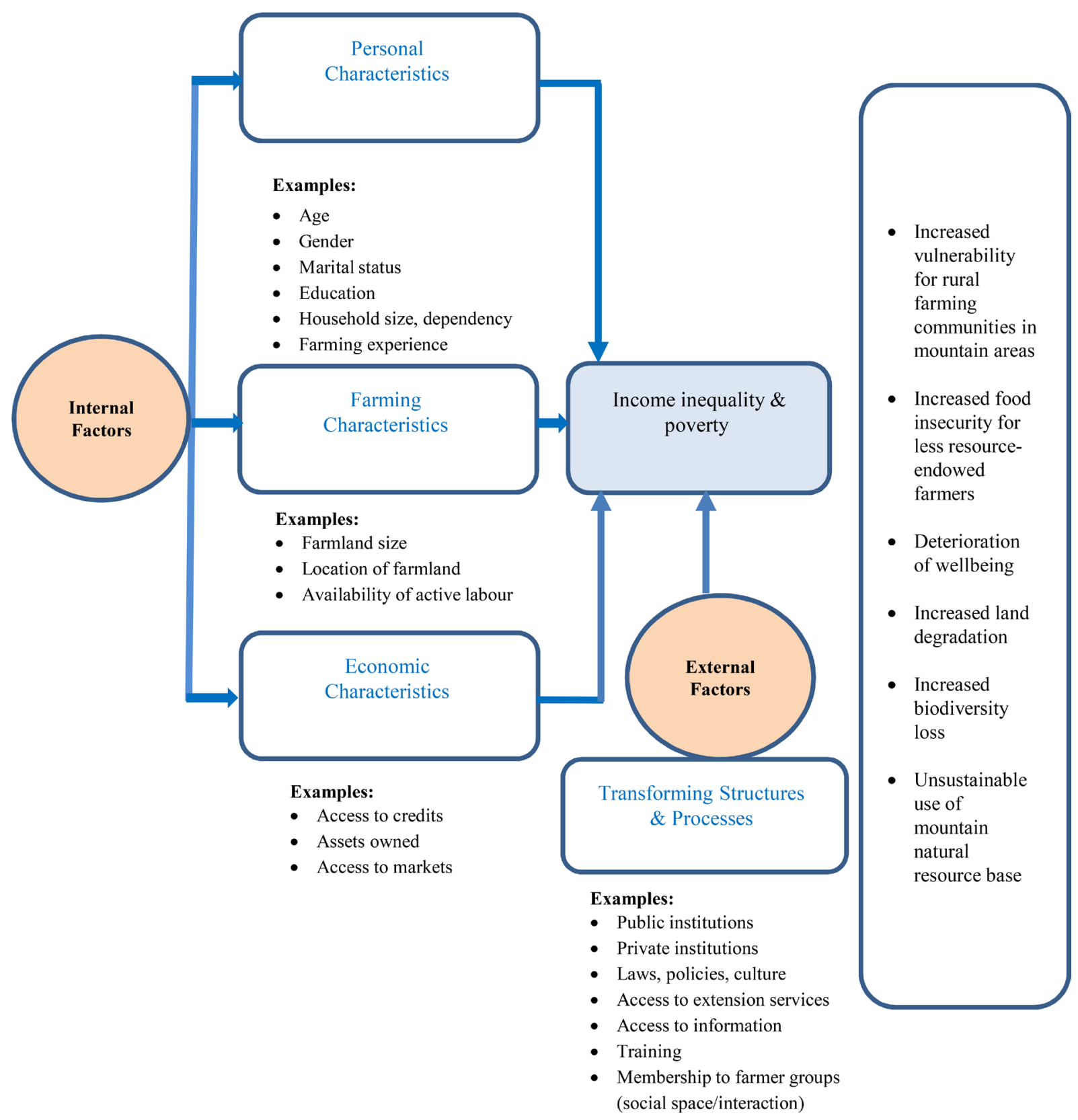

Figure 1. Conceptual framework for the causes and nature of income inequality and poverty in mountain areas. 
and after redistribution, just to mention a few. Our framework shows that the nature and level of income inequality is determined by four major characteristics or forces namely; the household personal characteristics (e.g. age and sex of household head, education, household size, dependency ratio and type of household if extended family or otherwise); farming characteristics (e.g. farmland size and location); economic characteristics (e.g. access to credits, asset ownership, GDP per capita, globalisation, types of technology used etc.); and existing transforming structures and processes (e.g. public and private institutions, laws, policies, plans, culture, provision of extension services, information and training, as well as, interaction and social space in the community). Macro-economic characteristics impact income inequality through economic growth (Kenworthy, 2011) as well as, globalisation and technological change (Katz \& Autor, 1999). Just as important, age and dependency ratios can strongly impact labour supply and therefore earnings from labour. Demographic factors can impact income redistribution which in turn can affect demographic characteristics: for example, low income redistribution can lead to the formation of extended families as an alternative protection to poverty risks (see Bergh, 2005 for a detailed discussion on the impact of redistribution). In the mountain areas context, we view income inequality as socially undesirable for three major reasons. Firstly, it affects the capacity of less resource-endowed farmers to produce enough food for their families making them more vulnerable to hunger and poverty. Secondly, it deteriorates not only the farmers' welfare but also the land resources and agro-ecologies of mountain areas leading to increased loss of biodiversity. Thirdly, it is a major cause of unsustainable use of mountain natural resource base which in turn accelerates more income poverty and inequality in mountain areas (Kirui, 2016).

It is important to add that, the overall debate on the relationship between inequality and economic growth seems to be quite polarized in the literature. On one hand, there are scholars who argue that increases in inequality lead to lower growth levels (see Galor \& Zeira, 1993; Alesina \& Rodrik, 1994; Alesina \& Perotti, 1996; Benabou, 1996). Alesina and Rodrik (1994) for example, show that taxation and redistributive government expenditures have negative effects on capital accumulation, and therefore, they are negatively correlated with growth. Using the socio-political instability approach, Alesina and Perotti (1996) argue that individuals within highly unequal societies have incentives to engage in activities such as crime that may destabilize the society. This approach also suggests an inverse relationship between growth and income inequality. On the other hand, some scholars suggest a positive association between inequality and growth (Kaldor \& Kaldor 1960; Mirrlees, 1971; Bourguignon, 1981; Forbes, 2000). Kaldor and Kaldor (1960) for example, argue that the marginal propensity to save of poor people is smaller than that of rich people. Then, if the saving rate is positively associated with investment rate, and investment affects the growth positively, the more unequal an economy is the faster it would grow. Mirrlees (1971) also affirms that, pay compression structures that do not compensate for 
merit would lead societies to be more equal. Yet, they would also have an inverse effect on individuals' incentives, which are the decisive factors behind outstanding achievements. Elsewhere, Bourguignon (1981) used a convex saving function to show that the initial distribution has positive effects on the aggregate output. In other words, the higher the initial distribution is, the higher the aggregate output would be. Investment indivisibilities, is another argument that is used to show the positive relationship between inequality and growth. Since a large amount of money is needed for any new investment, and in the presence of ineffective capital market that prevents pooling resources by small investors, wealth concentration would be the result that can lead to a faster growth. However, it is worth noting that, some studies have indicated both negative and positive relationships (Castells-Quintana \& Royuela, 2014; Neves \& Silva, 2014; Gründler \& Scheuermeyer, 2015; Henderson et al., 2015; Kennedy et al., 2017; Barro, 2000; Naguib, 2017). Barro (2000) for example, found a positive relationship between growth and inequality for rich societies, but a negative relationship for poor societies.

\section{Study Area and Methodology}

\subsection{Study Area}

The study was conducted in Uluguru Mountains covering fourteen hamlets (Figure 2) in the wards of Mlimani and Luhungo (Morogoro Municipality), and Mzumbe (Mvomero district) in Morogoro, Tanzania. Located at altitudes of between 650 and 1400 metres above sea level, the study hamlets falls within the mountains' range. Geologists classify a mountain as a landform that rises at least

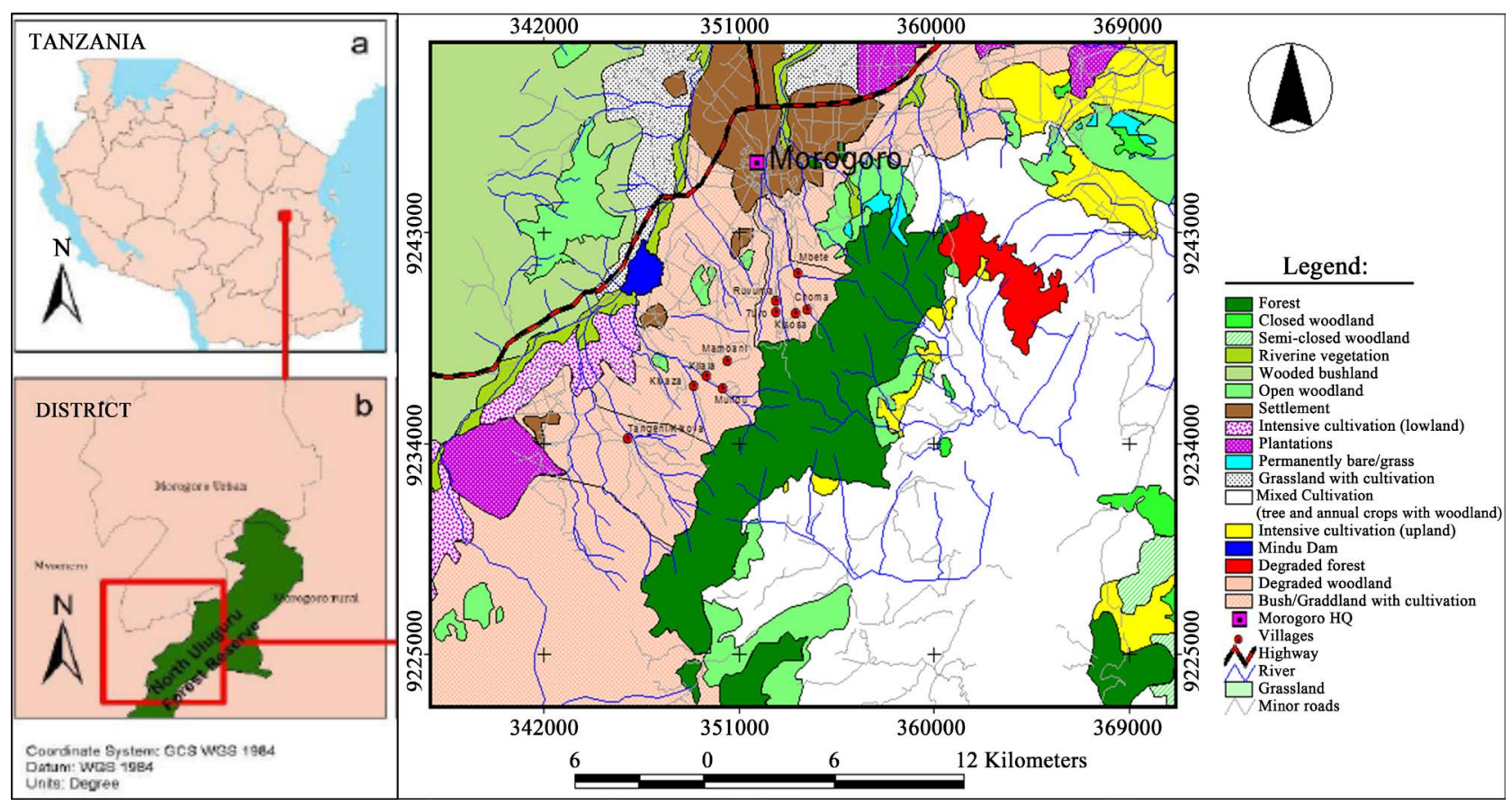

Figure 2. Map showing the location of the study area and major land uses. 
300 meters or more above its surrounding (National Geographic Website, n.d.). The Uluguru Mountains run approximately north-south with altitudes of up to 2630 metres above sea level at their highest point (EAMCSEF website, n.d) and their range contains a nature reserve which constitutes the Uluguru North, Uluguru Soutn and Bunduki Forest Reserves. About fifty villages border the Uruguru Forestry Reserve with population of over 151,000 found within the mountain area (ibid). Though harbour many endemic flora and fauna species, the Uluguru Mountains, as for other mountain areas in the world, are generally vulnerable to many natural and anthropogenic threats, including frequent fires, land cover change and agricultural intensification, just to mention a few.

The vegetation of the area is extremely variable ranging from drier lowland coastal forest to transitional rainforests, sub-montane, montane and upper montane forest types, as well as the afromontane grasslands on the Lukwangule plateau. All these ecosystems are rich in endemic species making them of high conservation priority. However, land degradation in the area is rampant due to existence of unsustainable anthropologic activities (Yanda \& Munishi, 2007; William, 2010; Harrison \& Mdee, 2017; Massawe et al., 2019). The mountains also serve as a water catchment and water source for populations living downstream in Morogoro rural and Municipality as well as other residents in the Dar es Salaam City and the Ruvu/Wami River Catchments. Thus, we purposefully selected the study area not only for its importance as a water catchment, but also as an enormous biodiversity hotspot which is encountered by the challenge of increasing human activities that threaten biodiversity and environmental integrity.

\subsection{Sampling and Data Collection}

The study used the multi-stage sampling procedure to select the study villages and sample households. In the first stage, fourteen hamlets were selected decisively based on their participation in the previous agroforestry related projects. In the second stage, households were stratified into strata according to wealth ranks assigned by UMPWSP (WCST, 2010). This ranking exercise eventually resulted in five types of wealth groups namely "very rich", "rich" "medium", "poor" and "very poor". The "very rich" and "rich" households were relatively a small group, covering only about $13 \%$ of the total households. They were food secure all year round and had a fairly secure livelihood base. The "medium" wealth class constituted about $35 \%$ of the households, with a smaller base of assets to draw on, but the majority of the households in this class were still food secure all year round. The "poor" and "very poor" households (combined together) made up more than half of the total households (52\%). The third stage entailed the selection of sample households from each stratum using the proportionate probability sampling procedure. The purpose of using wealth ranks, apart from understanding the perceptions of communities in the study area about poverty and wealth gained from the wealth ranking exercise, was to ensure that the sample drawn and quantitative analyses represent the full range of livelihood 
circumstances in the study area, rather than being accidentally clustered around the mode of range. The distribution of sample size by hamlets is given in Table 1.

The study used both primary and secondary data. Prior to commencement of fieldwork, we hired six enumerators to assist during data collection. These were trained on how to administer questionnaires and use other research tools (checklists and guidelines). They were also reminded about the research ethics they should comply with. The actual fieldwork started with a reconnaissance survey to get an overview and understanding of the study area and applicability of the questionnaire. During the reconnaissance survey the household questionnaire was pre-test to a small number of respondents before the actual fieldwork to check for their relevance to the study area and objectives. This was followed by the main survey which used different research tools and techniques, including structured questionnaires, interviews with key informants (selected based on their involvement in agroforestry-related initiatives) and Focus Group Discussions (FGDs).

The FGDs were attended by at least 10 participants per village representing different socioeconomic groups that existed in the area, including the rich, poor, youth and women, men, abled and disabled people. In addition, direct observation served as a complementary tool. In selecting the key informants for interview the snowball technique was used. The technique is particularly suitable when the population of interest is hard to reach and compiling a list of the population poses difficulties for the researcher (Etikan et al., 2016). It begins with a convenience number of initial subject which serves as "seeds," through which wave 1 subject is identified; wave 1 subject, in turn, identifies wave 2 subjects; and the number of interviewees consequently expands wave by wave-like a

Table 1. Distribution of sample sizes by sample hamlets.

\begin{tabular}{cccc}
\hline Hamlets & Households & Sample size $^{*}$ & $\%$ \\
\hline Tangeni village (5 hamlets) & 1030 & 66 & 32.8 \\
Kilala & 85 & 12 & 6.0 \\
Mundu & 145 & 15 & 7.5 \\
Mambani & 152 & 21 & 10.4 \\
Kivaza & 167 & 21 & 10.4 \\
Mbete & 22 & 9 & 4.5 \\
Ruvuma & 72 & 15 & 7.5 \\
Choma & 210 & 21 & 10.4 \\
Kisosa & 84 & 12 & 6.0 \\
Tulo & 42 & 9 & 4.5 \\
TOTAL & $\mathbf{2 0 0 9}$ & $\mathbf{2 0 1}$ & $\mathbf{1 0 0}$ \\
\hline
\end{tabular}

*The total sample size used in the final analysis (after data cleaning and removal of outliers) was 154 households. 
snowball growing in size as it rolls down a hill (Heckathorn, 2015).

\subsection{Data Processing and Analysis}

The results of qualitative analysis poverty using the wealth ranking results were complemented with quantitative analysis of income inequality and drivers of income inequality using the Gini coefficient and Lorenz curves, as well as, the coefficient of variation (CV) measure adapted from Adams (1994). The percentile shares quantify the proportions of total outcome (for example, of total income) that go to different groups defined in terms of their relative ranks in the distribution (ibid). The approach provides more details about the processes that cause the various distribution changes which may either increase or decrease the Gini coefficient (Akee et al., 2017). The percentile shares approach is more useful in cases where time series data is used but it also compliments the analysis of income inequality using cross-sectional data. The approach addresses the interpretation limitation inherent in specific values of the Gini coefficient (i.e., apart from the minimum and the maximum, these specific values of these Gini coefficient are difficult to interpret in an absolute sense) (Jann, 2016).

Our analysis of income inequality using percentile shares followed the approach presented by Jann (2016). The approach is also applied by many other scholars, including Atkinson et al. (2011); Piketty \& Saez (2014), and Piketty (2014). According to Jann (2016), a percentile share $S=\left(p_{1}, p_{2}\right)$, with $S=\left(p_{1}, p_{2}\right)$ is equal to the proportion of total outcome falls into the quantile interval $\left(Q_{p 1}, Q_{p 2}\right)$ or, put differently, the proportion of total outcome relating to the population segment from relative rank $p_{1}$ to relative rank $p_{2}$ in the list of ordered outcomes. This is equal to the difference between the Lorenz ordinates for $p_{1}$ and $p_{2}$ as expressed in Equation (6).

$$
S=\left(p_{1}, p_{2}\right)=L\left(p_{2}\right)-L\left(p_{1}\right)
$$

In the finite population, Equation (6) can be rewritten as in Equation (7).

$$
S\left(p_{1}, p_{2}\right)=\frac{\sum_{I=1}^{N} Y_{i} I_{Y_{i} \leq Q_{p_{2}}}}{\sum_{i=1}^{N} Y_{i=1}}-\frac{\sum_{I=1}^{N} Y_{i} I_{Y_{i} \leq Q_{p_{1}}}}{\sum_{i=1}^{N} Y_{i=1}}=\frac{\sum_{I=1}^{N} Y_{i}\left(I_{Y_{i} \leq Q_{p_{2}}}-I_{Y_{i} \leq Q_{p_{1}}}\right)}{\sum_{i=1}^{N} Y_{i=1}}
$$

In a simplified notation, we can rewrite Equation (7) by equating $S_{\ell}^{j}$ to $S\left(p_{\ell-1}, p_{l}\right)$, and $s(p)$ to $\left[S_{1} S_{2} \cdots S_{k}\right]$, the $1 * k$ vector of a disjunctive and exhaustive set of percentile shares across the domain of $p$ using cut-offs $p=\left[\begin{array}{llll}p_{0} & p_{1} & \cdots & p_{k}\end{array}\right]$, with $p_{\ell-1}<p_{\ell}$ for all $\ell=0, \cdots, k$ and $p_{0}=0$, and $p_{k}=1$. We then used the Lorenze curve and Gini index to measure income inequality among households using the per capita income (PCI), comulative percent of household size and cumulative percent of PCI.

As mentioned earlier, the Gini index is a widely used and favoured measure of income inequality over other alternatives because this index can be applied to both time series and cross-sectional data simultaneously (Sen, 1999; Todaro \& Smith, 2012). The value of the Gini Index ranges from 0 to 1 . With the value 1 , 
the Gini coefficient represents perfect unequal distribution of income, while with the value 0 , it represents perfect equality of income (Bastos et al., 2009). Links with the Lorenz curve make the Gini coefficient an attractive statistic for the decomposition by income components, as the Lorenz curve graphically represents the Gini coefficient. The concentration coefficient of each income component with respect to total income is obtained from a concentration curve (Pyatt et al., 1980; Nitta et al., 2020). However, it should be noted here that, the Gini coefficient (or concentration coefficient) cannot be used to rank distributions if the Lorenz curves (or concentration curves) intersect. It fails the decomposability axiom if the sub-vectors of income overlap. According to Litchfield (1999), there are alternative ways to decompose the Gini, however the component terms of total inequality are not always intuitively or mathematically appealing. Notwithstanding this concern the Gini coefficient still remains a popular inequality measure of total inequality and as a decomposable measure.

Using the CV approach, we decomposed the total household incomes into three major categories of income namely; income from crops, income from timber products (TPs), and income from off-farm activities (including, transfers, wages, salaries, retailing as well as the sale of non-farm products and other non-farm incomes). We purposefully used CV to pinpoint the contribution of these three categories of income sources to total income inequality. This is useful because conventionally, most studies have often attempted to evaluate the distributional impact of certain types of income by merely comparing the size of distribution of that particular income with that of the total rural income as a whole. Because it neglects the twin issues of income weights and covariance between income sources, any approach, which solely compares the size distribution of one particular income with that of total income, is likely to arrive at erroneous conclusions regarding the distributional impact of that particular income (Adams, 1994; Birthal \& Singh, 1995). Corresponding to the CV, we applied the decomposition formula presented in Equation (8).

$$
\begin{aligned}
& \sum w_{i} c_{i}=w_{i}=\frac{\mu_{i}}{\mu}, \\
& c_{i}=\rho_{i}\left[\left(\delta_{i} / \mu_{i}\right) /(\delta / \mu)\right]
\end{aligned}
$$

where, $w_{i} c_{i}$ is the factor inequality weight of the $i$-th source in overall inequality, $\mu_{i}$ is the mean income from the $i$-th source, $c_{i}$ is the relative concentration coefficient of the $i$-th source in overall inequality, $\rho_{i}$ is the correlation coefficient between the $i$-th source and the total income, and $\delta_{i}$ is the covariance involving the $i$-th income source. We define the mean income, $\mu$ as:

$$
\mu=\frac{1}{n} \sum_{i=1}^{n} y_{i}
$$

where, $y_{i}$ is the series of income from the $i$-th source, and $n$ is the sample size.

We estimated total household income using the step by step multiple linear regression model (Lovell \& Prescott, 1970) as expressed in Equation (10). 


$$
y^{*}=\beta_{0}+\beta_{1} V H A+\beta_{2} S F L+\beta_{3} A H H+\beta_{4} H H S+\varepsilon
$$

where $y^{*}$ is the dependent variable (estimated income); $\beta_{i}$ is the regression coefficient of the $\mathrm{i}$-th independent variable; The varable " $V H A$ " represents the total value of household assets; "SFL" represents the size of farmland in acres, " $A H H$ " represents the age of the hosehold head; " $H H S$ " is the household size; and $\varepsilon$ is the error term.

The incomes were estimated for both pooled and disaggregated samples. The disaggregation was done based on selected personal household characteristics (specifically the gender of hosehold head), farming characteristics (farmland location), as well as, transforming structures and processes (access to extension services and membership to community-based financial institutions such as SACCOS and VICOBA).

\section{Results and Discussion}

\subsection{Descriptive Statistics and Income Percentile Shares}

The descriptive statistics and results of income percentile shares for the pooled sample $(N=154)$ are summarised in Table 2 and Table 3 respectively. The

Table 2. Descriptive statistics for household income (TZS) (pooled sample, $N=154$ ).

\begin{tabular}{|c|c|c|}
\hline & Statistic & Std. Error \\
\hline Mean & $1,478,394.27$ & $159,023.57$ \\
\hline \multirow{2}{*}{$95 \%$ CI for Mean } & $1,164,228.84$ & \\
\hline & $1,792,559.70$ & \\
\hline 5\% Trimmed Mean & $1,195,652.20$ & \\
\hline Median & $814,609.00$ & \\
\hline Variance & $3,894,428,529,082.80$ & \\
\hline Std. Deviation & $1,973,430.65$ & \\
\hline Minimum & $50,877.50$ & \\
\hline Maximum & $16,100,000.00$ & \\
\hline Range & $16,028,672.50$ & \\
\hline Interquartile Range & $1,761,423.50$ & \\
\hline Skewness & 3.66 & 0.20 \\
\hline Kurtosis & 20.38 & 0.39 \\
\hline
\end{tabular}

Table 3. Household income percentiles for pooled sample $(N=154)$.

\begin{tabular}{cccccccc}
\hline & \multicolumn{7}{c}{ Percentiles } \\
\cline { 2 - 7 } & $\mathbf{5}$ & $\mathbf{1 0}$ & $\mathbf{2 5}$ & $\mathbf{5 0}$ & $\mathbf{7 5}$ & $\mathbf{9 0}$ & $\mathbf{9 5}$ \\
\hline \multicolumn{7}{c}{ Pooled sample $(\boldsymbol{N}=\mathbf{1 5 4})$} \\
\hline Weighted Average & 107,516 & 131,289 & 229,686 & 814,609 & $1,991,109$ & $3,342,022$ & $5,448,219$ \\
Tukey's Hinges & & & 230,718 & 814,609 & $1,964,077$ & & \\
\hline
\end{tabular}


income percentile shares for disaggregated samples are presented in Appendix 1. Our findings show that, the mean income and media for the pooled sample were TZS 1,478,394 (USD 637.65) and TZS 814,609 (USD 351.35) respectively. The interquartile range (IQR), also called the mid-spread, middle $50 \%$, or $\mathrm{H}$-spread was TZS 1,761,424 (759.73). IQR is a measure of statistical dispersion and is equal to the difference between $75^{\text {th }}$ and $25^{\text {th }}$ percentiles, or between upper and lower quartiles. Put different, the IQR is the first quartile subtracted from the third quartile. It is a trimmed estimator, defined as the $25 \%$ trimmed range, and is a commonly used robust measure of scale. It is a measure of variability, based on dividing a data set into quartiles. Quartiles divide a rank-ordered data set into four equal parts. The values that separate these parts are called the first quartile (Q1), second quartile (Q2), and the third quartile (Q3).

Our results (Table 3), indicate that $50 \%$ of the sample households in the study area had incomes of less than the mean income (i.e. TZS 814,609 or USD 351.35). About $90 \%$ of the households had incomes of less than TZS 3,342,022 (USD 1441.46) and only 10\% had income higher than this. These results suggest existence of income inequality in the study area. At the 50 percentile, the mean incomes for disaggregated analysis (Appendix 1) were the highest for farmers with farmland located far from homestead (TZS 2,449,922 equivalent to USD 970.42), followed by those of farmers who accessed extension services during the past two years (TZ 1,911,268 or USD 824.36) and farmers who were members of community-based financial institutions (TZS $1,682,776$ or USD 725.80). The mean incomes were the lowest for female-headed households (TZS 478,123, equivalent to USD 206.22), followed by farmers who did not access extension services (TZS 576,018 or USD 248.44), and farmers with farmland located close to homestead (TZS 582,370 or USD 251.18).

Farmlands located far from homestead were mostly found along the footsteps of the mountains or lowland areas where landholdings were relatively larger allowing for more intensification and crop revenues than the farmlands located in the upper gradients. This relationship is common in mountain areas. Mountain areas are considered as less favoured due to difficulties caused by short growing seasons, steep slopes at lower altitudes, or by a combination of the two (Council of the European Union, 2013, cited in Klima et al., 2020). Land holdings in high altitudes of mountain areas are limiting the scale of economic activities performed by farmers to increase farm income. Doucha et al. (2012), for example showed that, farmers in in Czech less favoured areas could rarely grow permanent pasture along with extensive cattle breeding or undertake any additional non-agricultural activities on farm (Kata, 2009). In fact, Kata (2009) confirmed decreasing value of income from operational farm activity toward higher altitude. In this circumstance, farm incomes may remain insufficient for smallholder farmers to undertake a profitable agricultural production. The influence of altitudinal variation on crop production and animal husbandry is also reported by Zhang et al. (2021) who investigated the response of altitudinal vegetation belts of the 
Tianshan Mountains of north-western China. They indicate that residents used the natural advantage of this area (i.e. the rich grassland resources due to its unique climatic conditions) to develop animal husbandry. However, the changes in the montane steppe belt were seen to greatly affect the scale of animal husbandry and the income of herdsmen (ibid). To address the challenges of agricultural production in mountain areas, farmers who are relatively better-off, tend to move along an altitude gradient—-to the lowlands (Klima et al., 2020).

\subsection{Income Inequality Using Gini Coefficient and Lorenz Curve}

The results of analysis of income inequality using the Gini index and Lorenz curves for income distribution are shown in Table 4 and Figure 3 respectively. The Gini coefficient for the pooled sample was 0.97 . The analysis of income data disaggregated by farmland location, gender of household head, access to extension services, and membership to community-based financial institutions, revealed that the latter (i.e. membership to community-based financial institutions) had the most equalizing effect on income. The Gini coefficient for farmers who were not members of any community-based was 0.77 implying that nonmembership to these institutions had a more inequalising effect on income. Importantly, income inequality was the highest among farmers with farmland located far from homestead (0.99). Overall, these findings support the argument that the size of households, access to extension service, credit access, and membership to social groups determine income distribution (Ogundipe, et al., 2019). Unexpectedly however, income inequality among farmers who accessed extension services was higher $(G=0.99)$ than that of their counterpart farmers who did not access the services $(G=0.94)$. We attribute this to variations in personal household characteristics (especially, age of the household head), and economic characteristics (size of farmland and value of asset) as indicated in our results of coefficients for the independent multiple linear regression models presented in Appendix 3. The coefficients for age of household, size of farmed land, and value

Table 4. Values of Gini coefficients.

\begin{tabular}{|c|c|c|}
\hline Variable & $\begin{array}{l}\text { Gini } \\
(G)\end{array}$ & $\begin{array}{c}\text { Lorenz Curve } \\
\text { (in Figure 3) }\end{array}$ \\
\hline Pooled sample $(N=154)$ & 0.97 & a) \\
\hline Farmers with farmland located close to homestead $(N=105)$ & 0.98 & b) \\
\hline Farmers with farmland located far from homestead $(N=49)$ & 0.99 & c) \\
\hline Female-headed households $(N=36)$ & 0.94 & d) \\
\hline Male-headed households $(N=118)$ & 0.97 & e) \\
\hline Farmers without access to extension services for the past 2 years $(N=90)$ & 0.94 & f) \\
\hline Farmers with access to extension services for the past 2 years $(N=64)$ & 0.99 & g) \\
\hline Farmers without membership to SACCOS/VICOBA $(N=111)$ & 0.77 & h) \\
\hline Farmers with membership to SACCOS/VICOBA $(N=43)$ & 0.00 & i) \\
\hline
\end{tabular}


(a) Pooled sample $(\mathrm{N}=154)$

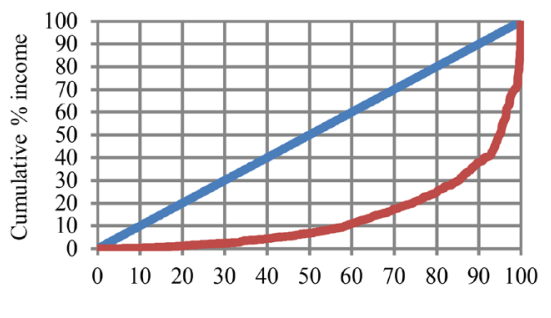

Cumulative \% household size

$\longrightarrow$ Equality line $\longrightarrow$ Lorenz curve

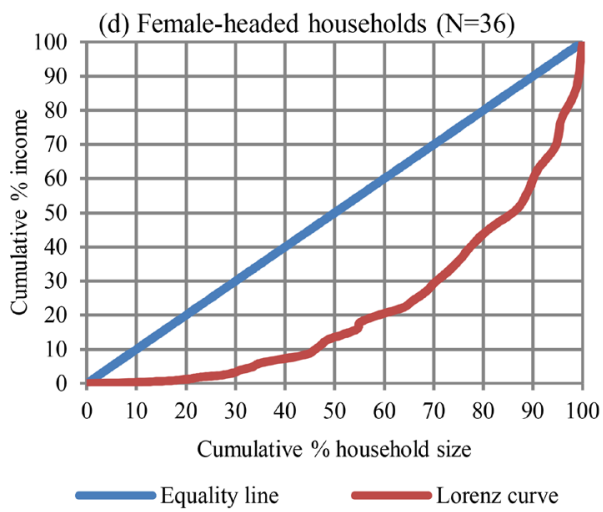

(g) Farmers who accessed extension services $(\mathrm{N}=64)$

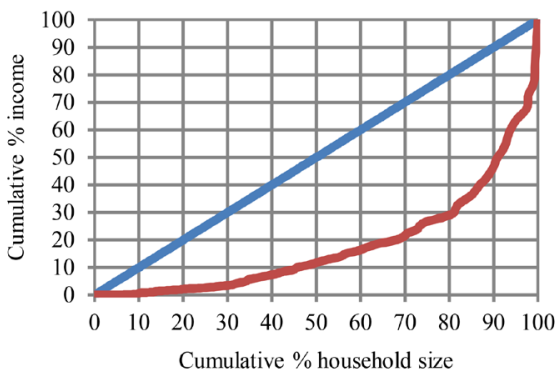

$\longrightarrow$ Equality line Lorenz curve (b) Households located close to

homestead, $\mathrm{d}<1 \mathrm{~km}(\mathrm{~N}=105)$

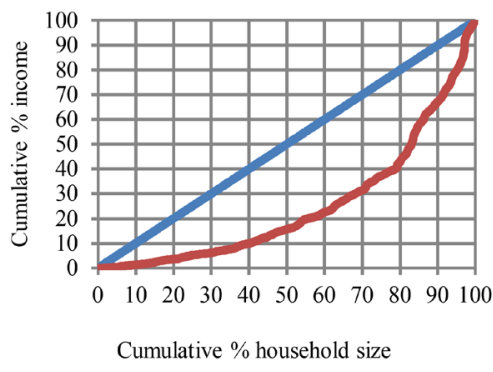

$\longrightarrow$ Equality line $\quad$ Lorenz curve

(e) Male-headed households ( $\mathrm{N}=118$ )

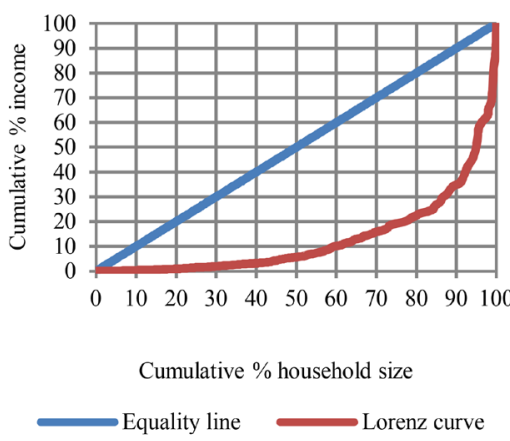

(h) Farmers who were not member of community-based financial institutions $(\mathrm{N}=111)$

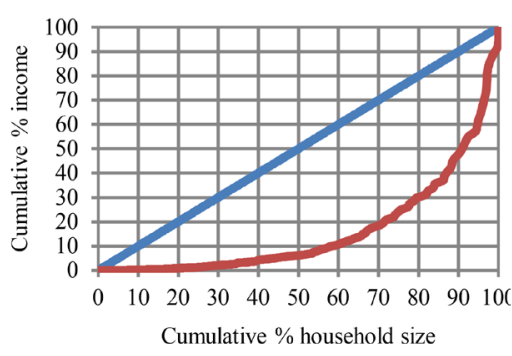

Equality line $\longrightarrow$ Lorenz curve (c) Hoseholds located far from

homestead, $\mathrm{d}>1 \mathrm{~km}(\mathrm{~N}=49)$

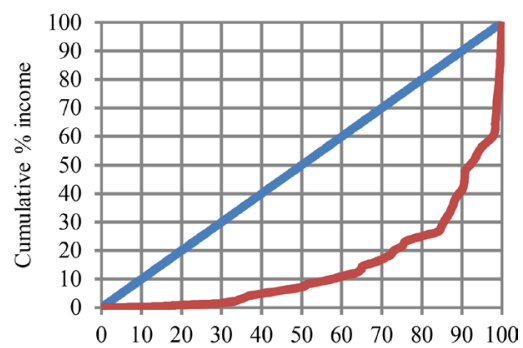

Cumulative \% household size

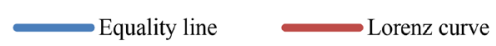

(f) Farmers who did not access extension services $(\mathrm{N}=90)$

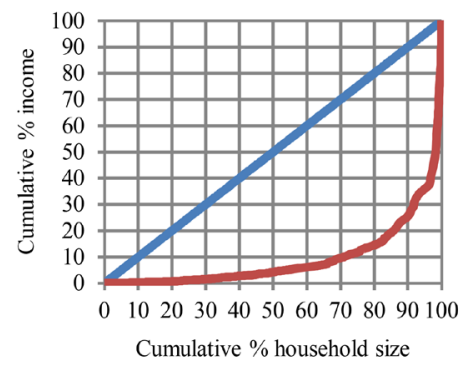

$\longrightarrow$ Equality line Lorenz curve

(i) Farmers who were members of community-based financial institutions $(\mathrm{N}=43)$

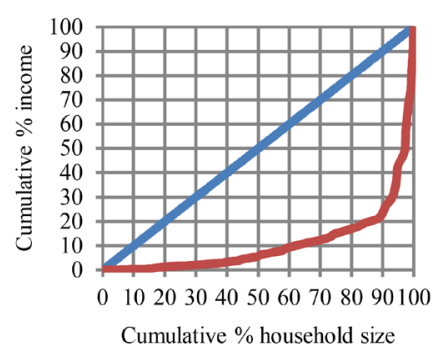

Equality line Lorenz curve

Figure 3. Lorenz curves for income distributions in Uluguru Mountains.

of household assets in the model of farmers who accessed extension services statistically significantly determined household income with $p$-values of $0.001,0.007$, and 0.000 respectively.

\subsection{Income Inequality Using Coeffient of Variation (CV)}

The results of analysis using CV for the pooled sample are presented in Table 5. Crop production was the main source of income in the agroforestry systems of the study area averaging at around TZS 1,101,401.60 (USD 475.05), followed by timber products (TZS 203,517.97, equivalent to USD 87.70). The contribution 
Table 5. Results of income inequality for the pooled sample measured using CV $(N=$ 154).

\begin{tabular}{ccccc}
\hline Parameter & Crop income & TPs income & Off-farm income & Total income \\
\hline$\mu_{1}$ & $1,101,401.57$ & $203,517.97$ & $173,474.73$ & $1,478,394.27$ \\
$W_{i}=\left(\mu_{i} / \mu\right)$ & 0.74 & 0.14 & 0.12 & \\
$\operatorname{Corr}\left(\rho_{i}\right)=\operatorname{correl}\left(y_{i} y\right)$ & 0.99 & 0.92 & 0.76 & \\
$\operatorname{Sdev}\left(\sigma_{i}\right)$ & $1,419,060.66$ & $266,455.56$ & $431,969.26$ & $1,973,430.65$ \\
$C_{i}=\rho_{i} *\left(\sigma_{i} / \mu_{i}\right) /(\sigma / \mu)$ & 0.95 & 0.90 & 1.42 & 1.0 \\
\hline$W_{i} c_{i}$ & 0.71 & 0.12 & 0.17 & \\
\hline
\end{tabular}

$\mu_{i}, \mu=$ Mean income for $i$-th source and for total income; $w_{i}=\left(\mu_{i} / \mu\right)=$ Ratio of mean income from $i$-th source to total mean income; $\operatorname{Corr}\left(\rho_{i}\right)=$ Correlation coefficient of $i$-th source and total income; $\operatorname{Sdev}\left(\sigma_{i}\right)=$ Covariance involving the $i$-th source of income; $c_{i}=$ Relative concentration of $i$-th source of income in overall inequality; $w_{i} c_{i}=$ Factor inequality weight of $i$-th source of income in overall inequality.

from non-farm activities (i.e other sources) was the lowest averaging at only TZS $173,474.73$ (USD 74.84) but the major income-inequality increasing source with a relative concentration in overall income which is greater than 1 (i.e. $c_{i}=1.42$ ). Agroforestry production systems (crops and timber products, TPs) registered relative concentration values which were slightly smaller than 1 (i.e. $c_{i}=0.95$ and 0.90 respectively) which implies that these two categories of household earnings were decreasing income-inequality among the smallholder farmers in the study area.

These findings support the assertion that, compared to other farming systems, agroforestry plays an important role in enhancing livelihoods of farmers in mountain areas (Neupane \& Thapa, 2001; Hossain et al., 2005; Safa, 2005; Rahman et al., 2007; Rahman 2011; Hasanuzzaman et al., 2014; Kiyani et al., 2017; Kadigi et al., 2021). In the Southern Province of Rwanda for example, Kiyani et al. (2017) indicate significant income disparity between farmers who practised agroforestry and those who did not practice it with mean annual income for the former being significantly higher than that of the latter farmers. Elsewhere in the Philippines and Nepal, Bugayong (2003) and Regmi (2003) also show similar findings.

For disaggregated analysis (Appendix 2), crops were an income-inequality increasing source for farmers with farmland located close to homestead $\left(c_{i}=1.33\right)$, farmers with farmland located far from homestead $\left(c_{i}=1.32\right)$, and female-headed households $\left(c_{i}=1.40\right)$, and farmers who did not access extension services $\left(c_{i}=1.05\right)$. Timber products (TPs) were income-inequality decreasing sources for farmers with farmland located far from homestead $\left(c_{i}=1.13\right)$, farmers who did not access extension services $\left(c_{i}=1.27\right)$ and farmers who were members of community-based financial institutions $\left(c_{i}=1.08\right)$. Other sources (nonfarm) were increasing income inequality for farmers with farmland located far from homestead $\left(c_{i}=2.83\right)$, male-headed households $\left(c_{i}=1.55\right)$, farmers with access to extension services $\left(c_{i}=1.83\right)$, and farmers who were not members of 
community-based financial institutions $\left(c_{i}=1.51\right)$. The remainder of disaggregated inequality analysis results showed $c_{i}<1$, implying that the respective items were income-inequality decreasing sources. Crops for example, were decreasing income-inequality for male-headed households $\left(c_{i}=0.94\right)$, for farmers who accessed extension services $\left(c_{i}=0.91\right)$, and for both farmers who were not members of community-based financial institutions $\left(c_{i}=0.94\right)$, as well as, the farmers who were members of these institutions $\left(c_{i}=0.99\right)$. In addition, timber products constituted an income-inequality decreasing source among farmers with farmland located close to homestead $\left(c_{i}=0.76\right)$, for both female-headed households (0.00) and male-headed households $\left(c_{i}=0.12\right)$, farmers who accessed extension services $\left(c_{i}=0.76\right)$, as well as, farmers who were members of community-based financial institutions $\left(c_{i}=0.94\right)$, and those who were not members $\left(c_{i}=0.94\right)$. Other sources (non-farm income generating activities) were decreasing income-inequality among farmers with farmlands located close to homestead $\left(c_{i}=0.00\right)$, female-headed households $\left(c_{i}=0.00\right)$, farmers who did not access extension services $\left(c_{i}=0.37\right)$, and farmers who were members of communitybased financial institutions $\left(c_{i}=0.94\right)$. This suggested the need to promote diversification of income sources in less favoured mountain areas.

The benefits of diversification are extensively discussed in the literature (see Ellis, 1998; Barrett et al., 2001; Lanjouw \& Lanjouw, 2001; Author \& Bryceson, 2002; Pattanayak et al., 2003; Kassie, 2017) with most of them revealing that non-farm earnings account for a substantial share of farm household income. The study by Kassie (2017) for example, shows that agroforestry and non-farm sources of income mutually determine significant economic returns. As such, Kassie (2017) recommended policy interventions that concurrently promote agroforestry and non-farm income diversification activities as these could not only enhance the sustainability of land management, but also maximise the farm households' economic returns. Non-farm income generating activities may include among others, wage labouring, property income, remittance, informal employment off-farm or non-agricultural activities on-farm, such as, weaving and brewing.

\subsection{Results of Step by Step Multiple Linear Regression Analysis}

Before running our model to get the descriptive statistics such as mean, media, range and interquantile range, we generated the P-P and histogram plots of regression standardized residual against continuous predictor variables (Figure 4) and used them to test the assumption of normality (i.e. if the plotted values vary more from a straight line or not). Where they vary more from the straight line, then the data could be considered to be not normally distributed, otherwise the data were considered to be normally distributed ( $\mathrm{Mu}, 2006)$. The P-P and histogram plots add value to regression analysis as they can expose a biased model far more effectively than the numeric output by displaying problematic patterns in the residuals. If the model is biased then the results cannot be trusted. If the re- 
sidual plots look good, then the analyst can proceed with the assessment of model statistics such as the adjusted R-squared $\left(R^{2}\right)$, which is also called the coefficient of determination, or the coefficient of multiple determination for multiple regression. It is used to measure the model's goodness-of-fit and it shows the percentage of the dependent variable variation that a linear model explains. Graphically, it evaluates the scatter of the data points around the fitted regression line (i.e. how well the model fits the data after fitting a linear regression model). For the same data set, higher $R^{2}$ values represent small differences between the observed data and the fitted values. However, it is important to note that high $R^{2}$ values are not necessarily good and small $R^{2}$ are not always a problem. Thus, before assessing numeric measures of goodness-of-fit, like $R^{2}$ it is advised to evaluate the residual plots. As indicated in Figure 4, as expected, the P-P plot and histogram of regression standardized residual against continuous predictor variables look good. We therefore continued with the analysis and the results for the pooled sample which are shown in Table 6. The $R^{2}$ values were greater than 0.5 for all the four steps (models), which implies that our model fitted
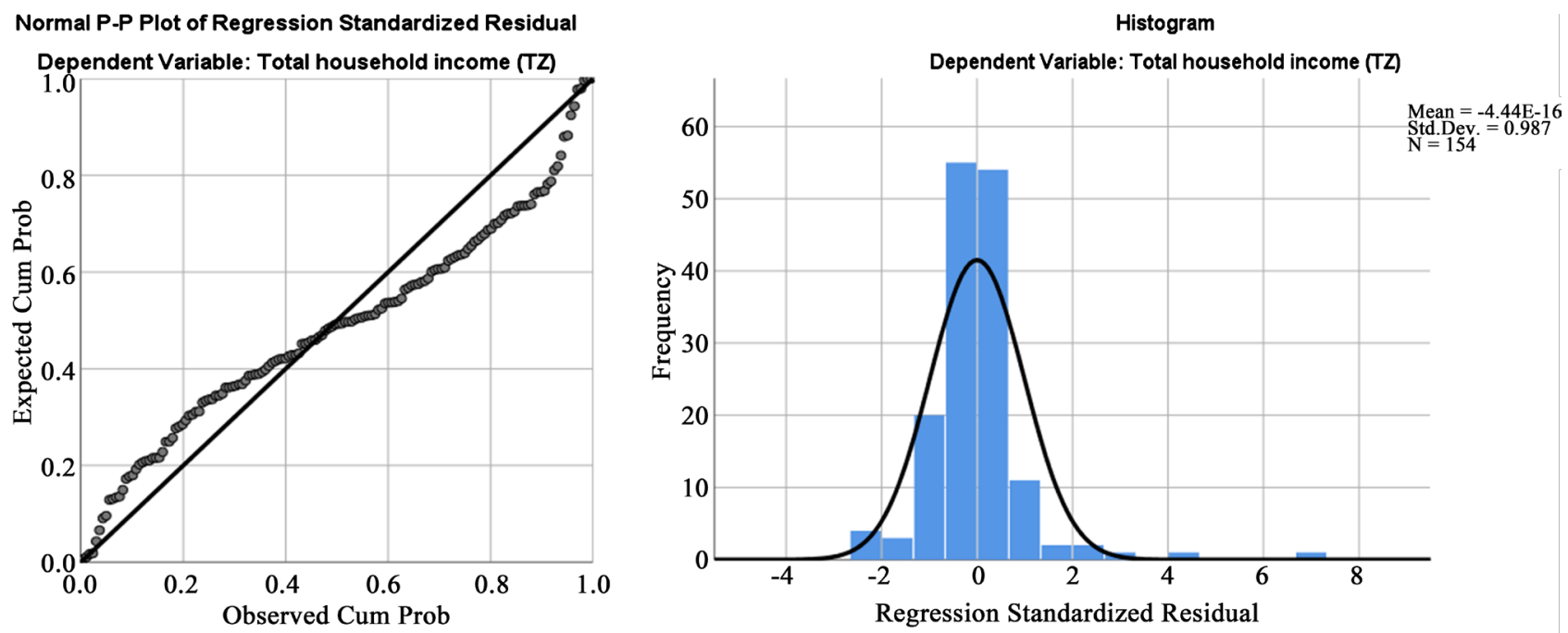

Figure 4. P-P plot and histogram of regression standardized residual against continuous predictor variables.

Table 6. Summary of a step by step multiple linear regression model for pooled sample using estimated income as dependent variable $(N=154)$.

\begin{tabular}{ccccc}
\hline Model & R & R Square & Adjusted R Square & Std. Error of the Estimate \\
\hline 1 & $0.752^{\mathrm{a}}$ & 0.566 & 0.563 & $1,300,000$ \\
2 & $0.771^{\mathrm{b}}$ & 0.595 & 0.589 & $1,260,000$ \\
3 & $0.789^{\mathrm{c}}$ & 0.623 & 0.616 & $1,220,000$ \\
4 & $0.806^{\mathrm{d}}$ & 0.649 & 0.640 & $1,180,000$ \\
\hline
\end{tabular}

aPredictors: (Constant), value of household assets (TZS); 'Predictors: (Constant), value of household assets (TZS), size of farmed land (acres); 'Predictors: (Constant), value of household assets (TZS), size of farmed land (acres), age of household head; dPredictors: (Constant), value of household assets (TZS), size of farmed land (acres), age of household head, household size. 
well the data.

The $R^{2}$ values for models using disaggregated data by farmland location, gender of household head, access to extension services, and membership to community-based financial institutions were also greater than 0.5 for all eight models (Table 7). The highest $R^{2}$ values were registered for the models of farmers who were not members of any community-based financial institution (0.714), and for female-headed households (0.685). The smallest $R^{2}$ values were registered for the models of farmers who were members of community-based financial institutions (0.500), and farmers who had access to extension services (0.570).

We also used the F-ratio in the ANOVA (Table 8 ) to test whether our overall regression model was a good fit for the data. The results show that the independent variables statistically significantly predicted the dependent variable in all our four models $(p=0.000)$ (i.e., the regression models were a good fit of the data). The $F$-values in the first step (model 1 ) and second step (model 2 ) were $F$ $(1,152)=198.09, p=0.000$; and $F(2,151)=110.82, p=0.000$, respectively. In the third and fourth steps the $F$-values were $F(3,150)=82.66, p=0.000$; and $F$ $(4,149)=69.02, p=0.000$ respectively.

We predicted total household income from value of household assets ( $V H A)$, size of farmland (SFL), age of household head $(A H H)$, and household size (HHS). This enabled us to test for the statistical significance of each of the independent

Table 7. Model summary with total household income as a dependent variable.

\begin{tabular}{|c|c|c|c|}
\hline $\mathbf{R}$ & R Square & Adjusted R Square & Std. Error of the Estimate \\
\hline \multicolumn{4}{|c|}{ Farmers with farmland located close to homestead $(N=105)$} \\
\hline $0.832^{\mathrm{a}}$ & 0.692 & 0.679 & $579,130.59$ \\
\hline \multicolumn{4}{|c|}{ Farmers with farmland located far from homestead $(N=49)$} \\
\hline $0.806^{\mathrm{a}}$ & 0.65 & 0.618 & $1,714,641.87$ \\
\hline \multicolumn{4}{|c|}{ Female headed households $(N=36)$} \\
\hline $0.849^{\mathrm{a}}$ & 0.721 & 0.685 & $475,160.57$ \\
\hline \multicolumn{4}{|c|}{ Male headed households (118) } \\
\hline $0.806^{\mathrm{a}}$ & 0.649 & 0.637 & $1,302,235.15$ \\
\hline \multicolumn{4}{|c|}{ Farmers without access to extension over the past two years $(N=90)$} \\
\hline $0.835^{\mathrm{a}}$ & 0.696 & 0.682 & $638,128.17$ \\
\hline \multicolumn{4}{|c|}{ Farmers with access to extension over the past two years $(N=64)$} \\
\hline $0.773^{\mathrm{a}}$ & 0.597 & 0.570 & $1,648,786.44$ \\
\hline \multicolumn{4}{|c|}{ Farmers without membership to SACCOS/VICOBA $(N=111)$} \\
\hline $0.851^{\mathrm{a}}$ & 0.724 & 0.714 & $1,092,361.18$ \\
\hline \multicolumn{4}{|c|}{ Farmers with membership to SACCOS/VICOBA $(N=43)$} \\
\hline $0.740^{\mathrm{a}}$ & 0.548 & 0.500 & $1,206,961.55$ \\
\hline
\end{tabular}

aPredictors: (Constant), Value of household assets (TZS), Age of household head, Size of farmed land (acres), Household size. 
Table 8. ANOVA results of a step by step multiple linear regression model for pooled sample $(N=154)$.

\begin{tabular}{ccccccc}
\hline Model $^{\text {a }}$ & & Sum of Squares & df & Mean Square & $F$ & Sig. \\
\hline 1 & Regression & $3.37 \mathrm{E}+14$ & 1 & $3.37 \mathrm{E}+14$ & 198.085 & $0.000^{\mathrm{b}}$ \\
& Residual & $2.59 \mathrm{E}+14$ & 152 & $1.70 \mathrm{E}+12$ & & \\
& Total & $5.96 \mathrm{E}+14$ & 153 & & & \\
2 & Regression & $3.54 \mathrm{E}+14$ & 2 & $1.77 \mathrm{E}+14$ & 110.816 & $0.000^{\mathrm{c}}$ \\
& Residual & $2.41 \mathrm{E}+14$ & 151 & $1.60 \mathrm{E}+12$ & & \\
& Total & $5.96 \mathrm{E}+14$ & 153 & & & \\
\multirow{2}{*}{3} & Regression & $3.71 \mathrm{E}+14$ & 3 & $1.24 \mathrm{E}+14$ & 82.664 & $0.000^{\mathrm{d}}$ \\
& Residual & $2.25 \mathrm{E}+14$ & 150 & $1.50 \mathrm{E}+12$ & & \\
& Total & $5.96 \mathrm{E}+14$ & 153 & & & \\
& Regression & $3.87 \mathrm{E}+14$ & 4 & $9.67 \mathrm{E}+13$ & 69.015 & $0.000^{\mathrm{e}}$ \\
& Residual & $2.09 \mathrm{E}+14$ & 149 & $1.40 \mathrm{E}+12$ & & \\
& Total & $5.96 \mathrm{E}+14$ & 153 & & & \\
\hline
\end{tabular}

a Dependent Variable: Total household income (TZ); 'Predictors: (Constant), value of household assets (TZS); 'Predictors: (Constant), value of household assets (TZS), size of farmed land (acres); ${ }^{\text {Predictors: }}$ (Constant), value of household assets (TZS), size of farmed land (acres), age of household head; ${ }^{\text {ePredictors: }}$ (Constant), value of household assets (TZS), size of farmed land (acres), age of household head, household size.

variables (i.e. testing whether the unstandardized or standardized coefficients are equal to 0 (zero) in the population, that is, if $p<0.05$ ). It is important to note here that, the unstandardized coefficients indicate how much the dependent variable varies with an independent variable when all other independent variables are held constant. The results of coefficients are presented in Table 9.

From the results presented in Table 9, we conclude that the coefficients are statistically significantly different from 0 (zero) and that the unstandardized coefficients for the four independent variables (as shown in the final or fourth step) statistically significantly predicted household income, $F(4,149)=69.02, p$ $=0.000, R^{2}=0.640$. All our four variables added statistically to the prediction, $p$ $<0.05$. Using the coefficients we obtained in Table 9, we therefore present our general form of multiple linear regression equation to predict household income $\left(y^{*}\right)$ from the independent variables defined earlier and labelled as $V H A, S F L$, $A H H$, and $H H S$ in Equation (11).

$$
\begin{aligned}
y^{*}= & -1695006.90+0.131 V H A+211073.5 S F L 5 \\
& +45190.58 A H H-168438.62 H H S
\end{aligned}
$$

The coefficients of independent multiple regression analysis of separate models disaggregated by farmland location, gender of household head, access to extension services and membership to community-based financial institutions are presented in Appendix 3. The $p$-values are less than 0.05 for all coefficients, except for age of household head $(p=0.058)$, household size $(p=0.684)$, and size of farmland $(p=0.056)$ in the models of farmers with farmlands located 
Table 9. Coefficients of a step by step multiple linear regression model for pooled sample using total household income as dependent variable $(N=154)$.

\begin{tabular}{|c|c|c|c|c|c|c|}
\hline Model $^{*}$ & & $\begin{array}{l}\text { Unstandardized } \\
\text { Coefficients (B) }\end{array}$ & $\begin{array}{l}\text { Coefficients } \\
\text { (Std. Error }\end{array}$ & $\begin{array}{c}\text { Standardized } \\
\text { Coefficients (Beta) }\end{array}$ & $t$ & Sig. \\
\hline \multirow[t]{2}{*}{1} & (Constant) & $81,189.330$ & $144,593.382$ & & 0.562 & 0.575 \\
\hline & $V H A$ (TZS) & 0.165 & 0.012 & 0.752 & 14.074 & 0.000 \\
\hline \multirow[t]{3}{*}{2} & (Constant) & $-326,040.719$ & $187,115.752$ & & -1.742 & 0.083 \\
\hline & $V H A(\mathrm{TZS})$ & 0.140 & 0.014 & 0.640 & 10.293 & 0.000 \\
\hline & SFL (acres) & $187,378.247$ & $57,045.035$ & 0.204 & 3.285 & 0.001 \\
\hline \multirow[t]{4}{*}{3} & (Constant) & $-1,492,707.896$ & $391,777.315$ & & -3.810 & 0.000 \\
\hline & $V H A$ (TZS) & 0.124 & 0.014 & 0.567 & 8.868 & 0.000 \\
\hline & $S F L$ (acres) & $217,415.263$ & $55,917.828$ & 0.237 & 3.888 & 0.000 \\
\hline & $A H H$ (years) & $25,185.916$ & 7500.304 & 0.179 & 3.358 & 0.001 \\
\hline \multirow[t]{5}{*}{4} & (Constant) & $-1,695,006.895$ & $383,886.615$ & & -4.415 & 0.000 \\
\hline & $V H A$ (TZS) & 0.131 & 0.014 & 0.598 & 9.558 & 0.000 \\
\hline & SFL (acres) & $211,073.551$ & $54,141.316$ & 0.230 & 3.899 & 0.000 \\
\hline & $A H H$ (years) & $45,190.576$ & 9402.051 & 0.321 & 4.806 & 0.000 \\
\hline & $H H S$ & $-168,438.624$ & $50,327.357$ & -0.223 & -3.347 & 0.001 \\
\hline
\end{tabular}

*Dependent Variable: Total household income (TZ).

close homestead; as well as, for model of female-headed households with $p$ vlues of $0.096,0.762$, and 0.850 respectively. The coeffients for household size also yielded $p$ - values of less than 0.05 in models of farmers with access to extension services $(p=0.089)$ and farmers without membership to community-based financial institutions $(p=0.093)$.

The coefficients of our step by step multiple linear regression model for the pooled sample suggest that household assets, size of farmland, and age of household head positively influenced household income while the household size negatively influenced the household income. These results can be compared with findings of other previous studies. In Urban Ethiopia for example, Abebe (2020) employed Fields' (2003) regression based on decomposition technique to investigate the factors influencing income inequality using cross-sectional analysis. The study found age and household size to be negatively influencing expenditure and household income contributing to widen income inequality. In Malaysia, Ayyash and Sek (2020) found sex and age of household heads to be contributing negatively to inequality and had inequality decreasing effects, with negative impact on inequality. Elsewhere, in South Korea, Shin (2020) analysed data linking survey data with administrative data shows that wealth, employment status, family size, and education were significant contributors of income inequality. Income and loans were the two most significant factors contributing to wealth inequality. Shin (2020) indicated further that income derived from economic activity and loans based on the leverage in the financial market exacerbated wealth ine- 
quality as higher income groups tended to utilize more loans in the monetised economy, widening the gap between the rich and the poor.

As such, the mainstream literature on female-headed households and poverty indicates that female-headed households constitute the "poorest of the poor" (Chant, 2007; Liu \& Treviño, 2017), and several other studies have shown a link between female-headed households with poverty and low socioeconomic status (Goebel et al., 2010; Javed \& Asif, 2011; Montoya \& Teixeira, 2017). In 2019, Lebni et al. (2020) conducted a qualitative study among female-headed households in Kermanshah, West of Iran. They collected data through semi-structured interviews with female-headed households who were selected purposefully. They analysed their data using conventional qualitative content analysis and they found that female-headed households faced many challenges that could become a big threat or an opportunity.

\section{Conclusion and Policy Implication}

A study was conducted to investigate the nature and determinants of income inequality in mountain areas using the case of Uluguru Mountains in Tanzania. Specifically, the study used the cross-sectional research design, income percentile shares, Gini coefficient and Lorenz curves, as well as, the coefficient of variation $(\mathrm{CV})$, to pinpoint the nature of income inequality in the study area using both pooled and disaggregated data. The determinants of income inequality were investigated using the step by step multiple linear regression model. The results of analysis of income-inequality revealed existence of income inequality. At the 50 percentile, the mean incomes for disaggregated analysis were the highest for farmers with farmland located far from homestead, followed by those of farmers who accessed extension services during the past two years and farmers who were members of community-based financial institutions. The mean incomes were the lowest for female-headed households, followed by farmers who did not access extension services as well as farmers with farmland located close to homestead. The farmlands located far from homestead were mostly found along the footsteps of the mountains or lowland areas where landholdings were relatively larger allowing for more intensification and crop revenues than the farmlands located in the upper gradients. Membership to community-based financial institutions had the most equalizing effect on income. Income inequality was the highest among farmers with farmland located far from homestead. Unexpectedly however, income inequality amongst farmers who accessed extension services was higher than that of their counterpart farmers who did not access the services. We attribute this to variations in personal household characteristics (especially, age of the household head), and economic characteristics (size of farmland and value of asset).

Overall, crop production was the main source of income in the agroforestry systems of the study area, followed by timber products. The contribution of income from non-farm income generating activities was the lowest but these sources 
constituted a major income-inequality increasing component in the pooled sample. Agroforestry production systems (crops and timber) decreased incomeinequality in the study area. However, the results of disaggregated analysis showed that "non-farm sources" were decreasing income-inequality for farmers with farmlands located close to homestead, for female-headed households, for farmers who did not access extension services, and for farmers who were members of community-based financial institutions. This implies that diversification of income sources is an important strategy for reducing income inequality in mountain areas. Accordingly, policies and initiatives that aim to promote diversification of livelihoods are more likely to reduce income inequality in these areas and are therefore recommended.

The values of coefficients in our step by step multiple linear regression model suggested that household assets, size of farmland, and age of household head positively influenced household income and household size negatively influenced household income. Our results also suggest that, gender disparity remains one of the key issues to be addressed, and it should be taken into account in formulating future policies, especially those aiming to reduce inequality among populations in mountain areas and thus, improving living standards and well-being of smallholder farmers in these areas. In addition to promoting livelihood diversification, we therefore recommend tailor-made training and farm financing mechanism to help the less resource endowed farmers, including the female-headed households in mountain areas to raise their economic portfolios and social status.

\section{Acknowledgements}

This paper is based on a postgraduate research conducted under the Department of Forest and Environmental Economics of the Sokoine University of Agriculture (SUA) in Tanzania. The author would therefore wish to extend his sincere gratitude to Ms. Willickister R. Kadigi for allowing her raw data to be used for analysis in this paper, to the former and current heads of the Department of Forest and Environmental Economics at SUA, Prof. Jumanne Abdallah and Dr. Greyson Z. Nyamoga respectively, as well as the other academic staff in the Department for their enormous academic support. My sincere acknowledgements are also due to Mr. Raymond R. Kilenga, the Programme Officer of the Eastern Arc Mountains Conservation Endowment Fund; Ms. Bernadetha Chille, the Principle Forest Officer of the Uluguru Forest Nature Reserve; the respondents and village/hamlet leaders in the study area for their hands of support as well as excellent cooperation and inputs during data collection.

\section{Conflicts of Interest}

The author declares no conflicts of interest regarding the publication of this paper.

\section{References}

Abebe, G. M. (2020). Factors Influencing Income Inequality in Urban Ethiopia (CrossSectional Analysis). Science Research, 8, 115-127. 
https://doi.org/10.11648/j.sr.20200805.12

Adams, R. H. (1994). Non-Farm Income and Inequality in Rural Pakistan: A Decomposition Analysis. The Journal of Development Studies, 31, 110-133.

https://doi.org/10.1080/00220389408422350

Ahearn, M., Johnson, J., \& Strickland, R. (1985). The Distribution of Income and Wealth of Farm Operator Households. American Journal of Agricultural Economics, 67, $1087-$ 1094. https://doi.org/10.2307/1241378

Akee, R., Jones, M. R., \& Porter, S. R. (2017). Race Matters: Income Shares, Income Inequality, and Income Mobility for All U.S. Races. NBER Working Paper Series 23733, Cambridge: National Bureau of Economic Research. https://doi.org/10.3386/w23733 http://www.nber.org/papers/w23733

Alesina, A., \& Perotti, R. (1996). Income Distribution, Political Instability, and Investment. European Economic Review, 40, 1203-1228. https://doi.org/10.1016/0014-2921(95)00030-5

Alesina, A., \& Rodrik, D. (1994). Distributive Politics and Economic Growth. The Quarterly Journal of Economics, 109, 465-490. https://doi.org/10.2307/2118470

Atkinson, A. B., Piketty, T, \& Saez, E. (2011). Top Incomes in the Long Run of History. Journal of Economic Literature, 49, 3-71. https://doi.org/10.1257/jel.49.1.3

Author, E., \& Bryceson, D. F. (2002). Multiplex Livelihoods in Rural Africa: Recasting the Terms and Conditions of Gainful Employment. The Journal of Modern African Studies, 40, 1-28. https://doi.org/10.1017/S0022278X01003792

Ayyash, M., \& Sek, S. K. (2020). Decomposing Inequality in Household Consumption Expenditure in Malaysia. Economies, 8, 83. https://doi.org/10.3390/economies8040083

Barrett, C. B., Reardon, T., \& Webb, P. (2001). Nonfarm Income Diversification and Household Livelihood Strategies in Rural Africa: Concepts, Dynamics, and Policy Implications. Food Policy, 26, 315-331. https://doi.org/10.1016/S0306-9192(01)00014-8

Barro, R. J. (2000). Inequality and Growth in a Panel of Countries. Journal of Economic Growth, 5, 5-32. https://doi.org/10.1023/A:1009850119329

Bastos, A., Casaca, S. F., Nunes, F., \& Pereirinha, P. (2009). Women and Poverty: A Gender-Sensitive Approach. Journal of Socio-Economics, 38, 764-778.

https://doi.org/10.1016/j.socec.2009.03.008

Bedeian, A. G., \& Mossholder, K. W. (2000). On the Use of the Coefficient of Variation as a Measure of Diversity. Organisational Research Methods, 3, 285-297. https://doi.org/10.1177/109442810033005

Benabou, R. (1996). Inequality and Growth. NBER Chapters. NBER Macroeconomics Annual 1996, Volume 11, 11-92. https://doi.org/10.3386/w5658

Benedetti, I., Crescenzi, F., \& Laureti, T. (2020). Measuring Uncertainty for Poverty Indicators at Regional Level: The Case of Mediterranean Countries. Sustainability, 12, 8159. https://doi.org/10.3390/su12198159

Bergh, A. (2005). On the Counterfactual Problem of Welfare State Research: How Can We Measure Redistribution? European Sociological Review, 21, 345-357.

https://doi.org/10.1093/esr/jci024

Biewen, M. (2000). Income Inequality in Germany during the 1980s and 1990s. Review of Income and Wealth, 46, 1-19. https://doi.org/10.1111/j.1475-4991.2000.tb00388.x

Biewen, M. (2002). Bootstrap Inference for Inequality, Mobility and Poverty Measurement. Journal of Econometrics, 108, 317-342.

https://doi.org/10.1016/S0304-4076(01)00138-5

Birthal, P. S., \& Singh, M. K. (1995). Structure of Rural Income Inequality: A Study in 
Western Uttar Pradesh. Indian Journal of Agricultural Economics, 50, 168-175. https://ageconsearch.umn.edu/record/275016/files/04\%20Structure\%20of\%20Rural\%2 0Income\%20Inequality\%2002-APRIL-JUNE-1995-4.pdf

Bourguignon, F. (1981). Pareto Superiority of Unegalitarian Equilibria in Stiglitz' Model of Wealth Distribution with Convex Saving Function. Econometrica: Journal of the Econometric Society, 49, 1469-1475. http://www.jstor.org/stable/1911412

https://doi.org/10.2307/1911412

Bugayong, L. A. (2003). Socioeconomic and Environmental Benefits of Agroforestry Practices in a Community-Based Forest Management Site in the Philippines. The International Conference on Rural Livelihoods, Forests and Biodiversity, Bonn, 19-23 May 2003, 1-21.

Castells-Quintana, D., \& Royuela, V. (2014). Tracking Positive and Negative Effects of Inequality on Long-Run Growth (29 p.). Working Paper 2014/01, Barcelona: Regional Quantitative Analysis Research Group (AQR), Research Institute of Applied Economics (IREA), University of Barcelona.

Chant, S. (2007). Gender, Generation and Poverty: Exploring the "Feminisation of Poverty" in Africa, Asia and Latin America. Cheltenham: Edward Elgar Publishing.

Ciliberti, S., \& Frascarelli A. (2018). The CAP 2013 Reform of Direct Payments: Redistributive Effects and Impacts on Farm Income Concentration in Italy. Agricultural and Food Economics, 6, 19. https://doi.org/10.1186/s40100-018-0113-5

Council of the European Union (2013). Regulation (EU) No 1305/2013 of the European Parliament and of the Council of 17 December 2013 on Support for Rural Development by the European Agricultural Fund for Rural Development (EAFRD) and Repealing Council Regulation (EC) No 1698/2005. Brussels: European Parliament, Council of the European Union.

Cowell, F. A., \& Victoria-Feser, M. P. (2003). Distribution-Free Inference for Welfare Indices under Complete and Incomplete Information. Journal of Economic Inequality, 1, 191-219. https://doi.org/10.1023/B:JOEI.0000004637.12354.c7

Doucha, T., Štolbová, M., \& Lekešová, M. (2012). Assessment of Support for Farms in Czech Less Favoured Areas with Special Regards to Cattle Breeding. European Countryside, 3, 179-191. https://doi.org/10.2478/v10091-012-0022-7

El Benni, N., \& Finger, R. (2013). The Effect of Agricultural Policy Reforms on Income Inequality in Swiss Agriculture: An Analysis for Valley, Hill and Mountain Regions. Journal of Policy Modelling, 35, 638-651. https://doi.org/10.1016/j.jpolmod.2012.03.005 https://www.sciencedirect.com/science/article/abs/pii/S0161893812000385

Ellis, F. (1998) Household Strategies and Rural Livelihood Diversification. Journal of Development Studies, 35, 1-38. https://doi.org/10.1080/00220389808422553

Etikan, I., Alkassim, R., \& Abubakar, S. (2016). Comparison of Snowball Sampling and Sequential Sampling Technique. Biometrics \& Biostatistics International Journal, 3, 67. https://doi.org/10.15406/bbij.2016.03.00055

Fang, H., \& Rizzo J. A. (2011). Income Inequality Dynamics in Rural China from 1991 to 2006: The Role of Alternative Income Sources. Applied Economics Letters, 18, $1307-$ 1310. https://doi.org/10.1080/13504851.2010.535778

FAO (2013). Mountain Farming Is Family Farming: A Contribution from Mountain Areas to the International Year of Family Farming 2014 (97 p.). http://www.fao.org/docrep/019/i3480e/i3480e.pdf

Fields, G. S. (2003). Accounting for Income Inequality and Its Change: A New Method, with Application to the Distribution of Earnings in the United States. In S. W. Polachek (Ed.), Worker Well-Being and Public Policy (Research in Labour Economics, Vol. 22) (pp. 1-38). Bingley: Emerald Group Publishing Limited. 


\section{https://doi.org/10.1080/13504851.2010.535778}

Forbes, K. J. (2000). A Reassessment of the Relationship between Inequality and Growth. American Economic Review, 90, 869-887. https://doi.org/10.1257/aer.90.4.869

Foster, J., Greer, J., \& Thorbecke, E. (2010). The Foster-Greer-Thorbecke (FGT) Poverty Measures: 25 Years Later. The Journal of Economic Inequality, 8, 491-524. https://doi.org/10.1007/s10888-010-9136-1

Francese, M., \& Mulas-Granados, C. (2015). Functional Income Distribution and Its Role in Explaining Inequality (33 p.). IMF Working Paper No. WP/15/244, Washington DC: International Monetary Fund. https://doi.org/10.5089/9781513549828.001 https://www.imf.org/external/pubs/ft/wp/2015/wp15244.pdf

Galor, O., \& Zeira, J. (1993). Income Distribution and Macroeconomics. The Review of Economic Studies, 60, 35-52. https://doi.org/10.2307/2297811

Giorgi, G. M., \& Gigliarano, C. (2017). The Gini Concentration Index: A Review of the Inference Literature. The Journal of Economic Surveys, 31, 1130-1148.

https://doi.org/10.1111/joes.12185

Goebel A., Dodson, B., \& Hill, T. (2010). Urban Advantage or Urban Penalty? A Case Study of Female-Headed Households in a South African City. Health Place, 16, 573580. https://doi.org/10.1016/j.healthplace.2010.01.002

Gründler, K., \& Scheuermeyer, P. (2015). Income Inequality, Economic Growth, and the Effect of Redistribution. Würzburg Economic Papers, University of Würzburg, Würzburg, No. 95.

https://www.wiwi.uni-wuerzburg.de/fileadmin/wifak/Downloadpool/WEP/2015/wep95 .pdf

Harrison, E., \& Mdee A. (2017). Successful Small-Scale Irrigation or Environmental Destruction? The Political Ecology of Competing Claims on Water in the Uluguru Mountains, Tanzania. Journal of Political Ecology, 24, 407-424.

https://doi.org/10.2458/v24i1.20881

Hasanuzzaman, M., Mahmood, H., \& Saroar, M. (2014). Diversity and Preference of Agricultural Crops in the Cropland Agroforests of South-Western Bangladesh. International Journal of Agriculture and Crop Sciences, 7, 364-372.

Heckathorn, D. D. (2015). Snowball Versus Respondent-driven Sampling. Sociological Methodology, 41, 355-366. https://doi.org/10.1111/j.1467-9531.2011.01244.x

Henderson, D. J., Qian, J., \& Wang, L. (2015). The Inequality Growth Plateau. IZA Discussion Papers, No. 8771, Bonn: Institute for the Study of Labor (IZA). https://www.econstor.eu/bitstream/10419/107563/1/dp8771.pdf

Hoeffding, W. (1992). A Class of Statistics with Asymptotically Normal Distribution. In Breakthroughs in Statistics (pp. 308-334). Berlin/Heidelberg: Springer. https://doi.org/10.1007/978-1-4612-0919-5 20

Hossain, M. A., Alam, M. A., Rahman, M. M., Rahaman, M. A., \& Nobi M. N. (2005). Financial Variability of Shifting Cultivation versus Agroforestry Project: A Case Study in Chittagong Hill Tracts. International Journal of Agriculture and Biology, 1, 29-34.

Jaitiang, D., Huang, W., \& Yang, S. (2021). Does Income Inequality Exist among Urban Farmers? A Demonstration of Lorenz Curves from Northern Thailand. Sustainability, 13, 5119. https://doi.org/10.3390/su13095119

Jann, B. (2016). Assessing Inequality Using Percentile Shares. The Stata Journal, 16, 264-300. https://doi.org/10.1177/1536867X1601600202

Javed, Z. H., \& Asif, A. (2011). Female Households and Poverty: A Case Study of Faisalabad District. International Journal of Peace and Development Studies, 2, 37-44. 
Kadigi, W. R., Ngaga, Y. M., \& Kadigi R. M. J. (2021). Economic Viability of Smallholder Agroforestry and Beekeeping Projects in Uluguru Mountains: A Cost Benefit Analysis. Open Journal of Forestry, 11, 83-107. https://doi.org/10.4236/ojf.2021.112007

Kaldor, N., \& Kaldor, B. (1960). Essays on Economic Stability and Growth (Vol. 1). London: Duckworth.

Kassie, G. W. (2017). Agroforestry and Farm Income Diversification: Synergy or TradeOff? The Case of Ethiopia. Environmental Systems Research, 6, 1-14. https://doi.org/10.1186/s40068-017-0085-6

Kata, R. (2009). Farm Earnings in the Structure of Agricultural Family Sources of Income in Mountainous Areas. Problemy Zagospodarowania Ziem Górskich, 56, 149-159.

Kata, R., \& Wosiek, M. (2020). Inequality of Income in Agricultural Holdings in Poland in the Context of Sustainable Agricultural Development. Sustainability, 12, 4963. https://doi.org/10.3390/su12124963

Katz, L. F., \& Autor, D. H. (1999). Handbook of Labour Economics (pp. 1463-1555). Amsterdam: Elsevier. https://economics.mit.edu/files/11684

https://doi.org/10.1016/S1573-4463(99)03007-2

Keeney, M. (2000). The Distributional Impact of Direct Payments on Irish Farm Incomes. Journal of Agricultural Economics, 51, 252-263. https://doi.org/10.1111/j.1477-9552.2000.tb01227.x

Kennedy, T., Smyth, R., Valadkhani, A., \& Chen, G. (2017). Does Income Inequality Hinder Economic Growth? New Evidence Australian Taxation Statistics. Economic Modelling, 65, 119-128. https://doi.org/10.1016/j.econmod.2017.05.012

Kenworthy, L. (2011). Progress for the Poor. Oxford: Oxford University Press. https://doi.org/10.1093/acprof:oso/9780199591527.001.0001

Kessler, C. A., \& Stroosnijder, L. (2006). Land Degradation Assessment by Farmers in Bolivian Mountain Valleys. Land Degradation and Development, 17, 235-248. https://doi.org/10.1002/ldr.699

Kirui, O.K. (2016). Economics of Land Degradation and Improvement in Tanzania and Malawi. Chapter 20. In: E. Nkonya, E., A. Mirazabaev, \& J. von Braun (Eds.), Economics of Land Degradation and Improvements-A Global Assessment for Sustainable Development (pp. 609-649), Springer International Publishing.

https://doi.org/10.1007/978-3-319-19168-3 20

https://library.oapen.org/bitstream/id/f08b4a3f-6ab0-4b20-89f5-73aca59b2bf6/1001884 .pdf

Kiyani, P., J. Andoh, Y., \& Lee, D. K. (2017). Benefits and Challenges of Agroforestry Adoption: A Case of Musebeya Sector, Nyamagabe District in Southern Province of Rwanda. Forest Science and Technology, 13, 174-180. https://doi.org/10.1080/21580103.2017.1392367

Klima, K., Kliszcz, A., Puła, J., \& Lepiarczyk, A. (2020). Yield and Profitability of Crop Production in Mountain Less Favoured Areas. Agronomy, 10, 700. https://doi.org/10.3390/agronomy10050700

Kovacevic, M. S., \& Yung, W. (1997). Variance Estimation for Measures of Income Inequality and Polarization-An Empirical Study. Survey Methodology, 23, 41-52.

Langel, M., \& Tillé, Y. (2013). Variance Estimation of the Gini Index: Revisiting a Result Several Times Published. Journal of the Royal Statistical Society, 176, 521-540. https://doi.org/10.1111/j.1467-985X.2012.01048.x

Lanjouw, J. O., \& Lanjouw, P. (2001). The Rural Non-Farm Sector: Issues and Evidence from Developing Countries. Agricultural Economics, 26, 1-23. https://doi.org/10.1111/j.1574-0862.2001.tb00051.x 
Lebni, J. Y. L., Gharehghani, M. A. M., Soofizad, G., Khosravi, B., Ziapour, A., \& Irandoost, S. F. (2020). Challenges and Opportunities Confronting Female-Headed Households in Iran: A Qualitative Study. BMC Women's Health, 20, 183. https://doi.org/10.1186/s12905-020-01046-X

Li, J., Feldman, M. W., Li, S., \& Daily, G. C. (2011). Rural Household Income and Inequality under the Sloping Land Conversion Program in Western China. Proceedings of the National Academy of Sciences, 108, 7721-7726.

https://doi.org/10.1073/pnas.1101018108

Litchfield, J. A. (1999). Inequality: Methods and Tools. Text for World Bank's Web Site on Inequality, Poverty and Socio-Economic Performance.

http://www.clsbe.lisboa.ucp.pt/docentes/url/analeco2/Papers/Litchfield Inequality Me thods Tools.pdf

Liu, C. E. A., \& Treviño, R. (2017). Female-Headed Households and Living Conditions in Latin America. World Development, 1, 311-328.

https://doi.org/10.1016/j.worlddev.2016.10.008

Lovell, M. C., \& Prescott, E. (1970). Multiple Regression with Inequality Constraints: Pretesting Bias, Hypothesis Testing and Efficiency. Journal of the American Statistical Association, 65, 913-925. http://www.jstor.org/stable/2284597 https://doi.org/10.1080/01621459.1970.10481134

Masebo, N., \& Menamo, M. (2016). A Review Paper on: The Role of Agroforestry for Rehabilitation of Degraded Soil. Journal of Biology, Agriculture and Healthcare, 6, 128 135. https://core.ac.uk/download/pdf/234661932.pdf

Massawe, P. I., Mvena, A., Nyoki, D., \& Chambile, E. L. (2019). Effects of Anthropogenic Activities on Availability of Clean and safe Water: A Case of Uluguru Forest Catchment Areas of Morogoro, Tanzania. South Asian Journal of Development Research, 1, 114-123.

McDonald, S., Piesse, J., \& Van Zyl, J. (2005). Exploring Income Distribution and Poverty in South Africa. South African Journal of Economics, 68, 186-203.

Mills, J. A., \& Zandvakili, S. (1997). Statistical Inference via Bootstrapping for Measures of Inequality. Journal of Applied Econometrics, 12, 133-150. https://doi.org/10.1002/(SICI)1099-1255(199703)12:2<133::AID-JAE433>3.0.CO;2-H

Mirrlees, J. A. (1971). An Exploration in the Theory of Optimum Income Taxation. The Review of Economic Studies, 38, 175-208. https://doi.org/10.2307/2296779

Montoya, Á. J. A., \& Teixeira, K. M. D. (2017). Multidimensional Poverty in Nicaragua: Are Female-Headed Households Better Off? Social Indicators Research: An International and Interdisciplinary Journal for Quality-of-Life Measurement, 132, 1037-1063. https://doi.org/10.1007/s11205-016-1345-y

$\mathrm{Mu}, \mathrm{Z}$. (2006). Comparing the Statistical Tests for Homogeneity of Variances (53 p.). Electronic Theses and Dissertations, Paper 2212, Johnson City, TE: School of Graduate Studies, East Tennessee State University.

Naguib, C. (2017). The Relationship between Inequality and Growth: Evidence from New Data. Swiss Society of Economics and Statistics, 153, 183-225.

https://doi.org/10.1007/BF03399507

National Geographic Website (n.d.).

https://www.nationalgeographic.com/science/earth/surface-of-the-earth/mountains/\#: : :text=They\%20usually\%20have $\% 20$ steep $\% 2$ C $\% 20$ sloping,mountains\%20that $\% 20$ are $\%$ 20close\%20together

Neupane, R. P., \& Thapa, G. B. (2001). Impact of Agroforestry Intervention on Farm Income under the Subsistence Farming System of the Middle Hills, Nepal. Agroforestry 
Systems, 84, 157-167. https://doi.org/10.1016/S0167-8809(00)00203-6

Neves, P. C., \& Silva, S. M. T. (2014). Survey Article-Inequality and Growth: Uncovering the Main Conclusions from the Empirics. Journal of Development Studies, 50, 1-21. https://doi.org/10.1080/00220388.2013.841885

Nitta, A., Yamamoto, Y., Kondo, K., \& Sawauchi, D. (2020). Direct Payments to Japanese Farmers: Do They Reduce Rice Income Inequality? Lessons for Other Asian Countries. Journal of Policy Modeling, 42, 968-981. https://doi.org/10.1016/j.jpolmod.2020.02.006

Ogundipe, A. A., Ogunniyi, A., Olagunju, K., \& Asaleye, A. J. (2019). Poverty and Income Inequality in Rural Agrarian Household of South-Western Nigeria: The Gender Perspective. The Open Agriculture Journal, 13, 51-57. https://doi.org/10.2174/1874331501913010051

Ogwang, T. A. (2000). Convenient Method of Computing the Gini Index and Its Standard Error. Oxford Bulletin of Economics and Statistics, 62, 123-129. https://doi.org/10.1111/1468-0084.00164

Palmitesta, P., Provasi, C., \& Spera, C. (2000). Confidence Interval Estimation for Inequality Indices of the Gini Family. Computational Economics, 16, 137-147. https://doi.org/10.1023/A:1008761721593

Park, J., Kim, Y., \& Ju, A. (2021). Measuring Income Inequality Based on Unequally Distributed Income. Journal of Economic Interaction and Coordination, 16, 309-322. https://ink.springer.com/content/pdf/10.1007/s11403-020-00295-1.pdf https://doi.org/10.1007/s11403-020-00295-1

Pattanayak, S. K., Mercer, D. E., Sills, E., \& Yang, J. C. (2003). Taking Stock of Agroforestry Adoption Studies. Agroforestry Systems, 57, 173-186. https://doi.org/10.1023/A:1024809108210

Pélabon, C., Hilde, C. H., Einum, S., \& Gamelon, M. (2020). On the Use of the Coefficient of Variation to Quantify and Compare Trait Variation. Evolution Letters, 4, 180-188. https://doi.org/10.1002/evl3.171

Piketty, T. (2014). Capital in the Twenty-First Century. Cambridge, MA: Belknap Press. https://doi.org/10.4159/9780674369542

Piketty, T., \& Saez, E. (2014). Inequality in the Long Run. Science, 344, 838-843. https://doi.org/10.1126/science.1251936

Pyatt, G., Chen, C., \& Fei, J. (1980). The Distribution of Income by Factor Components. The Quarterly Journal of Economics, 95, 451-473. https://doi.org/10.2307/1885088

Rahman, S. A. (2011). Cost Benefit and Livelihood Impacts of Agroforestry in Bangladesh (172 p.). Saarbrucken: Lambert Academic Publishing.

Rahman, S. A., Farhan, K. M., Rahman, A. H. M. M., \& Imtiaj, A. (2007). An Economic Evaluation of the Multi-Strata Agroforestry System in Northern Bangladesh. Am-Eurasian Journal of Agriculture and Environmental Science, 2, 655-661.

Regmi, B. N. (2003). Contribution of Agroforestry for Rural Livelihoods: A Case of Dhading District, Nepal. The International Conference on Rural Livelihoods, Forests and Biodiversity, Bonn, 19 May 2003, 1-19.

Reyes, T., Quiroz, R., \& Msikula, S. (2005). Socio-Economic Comparison between Traditional and Improved Cultivation Methods in Agroforestry Systems, East Usambara Mountains, Tanzania. Environmental Management, 36, 682-690. https://doi.org/10.1007/s00267-004-7269-3

Safa, M. S. (2005). Socio-Economic Factors Affecting the Income of Small-Scale Agroforestry Farms in Hill Country Areas in Yemen: A Comparison of OLS and WLS Determinants. Small-Scale Forest Economics, Management and Policy, 4, 117-134. https://doi.org/10.1007/s11842-005-0008-7 
Salvati, L. (2014). A Socioeconomic Profile of Vulnerable Land to Desertification in Italy. Science of the Total Environment, 466, 287-299.

https://doi.org/10.1016/j.scitotenv.2013.06.091

Schechtman, E. (1991). On Estimating the Asymptotic Variance of a Function of U Statistics. The American Statistician, 45, 103-106. https://doi.org/10.1080/00031305.1991.10475778

Sen, A. (1997). On Income Inequality. Oxford: Clarendon Press.

Sen, A. (1999). Development as Freedom (384 p.). New Delhi: Oxford University Press.

Sharma, P., Singh, M. K., \& Tiwari, P. (2017). Agroforestry: A Land Degradation Control and Mitigation Approach. Bulletin of Environment, Pharmacology and Life Sciences, 6, 312-317.

Shin, K. (2020). A New Approach to Social Inequality: Inequality of Income and Wealth in South Korea. The Journal of Chinese Sociology, 7, 1-15. https://doi.org/10.1186/s40711-020-00126-7

Stuart, A. (1954). The Correlation between Variate-Values and Ranks in Samples from a Continuous Distributions. British Journal of Statistical Psychology, 7, 37-44. https://doi.org/10.1111/j.2044-8317.1954.tb00138.x

Templeton, S., \& Scherr, S. J. (1996). Population Pressure and the Microeconomy of Land Management in Hills and Mountains of Developing Countries (77 p.). Environment and Production Technology Division Discussion Paper O. 26, Washington DC: International Food Policy Research Institute.

Todaro, M. P., \& Smith, S. C. (2012). Economic Development (11th ed., 801 p.). Harlow: Addison-Wesley, Pearson.

https://shahroodut.ac.ir/fa/download.php?id=1111128678

Ullah, K., Mohsin, A. Q., Saboor, A., \& Baig, S. (2020). Financial Inclusion, Socioeconomic Disaster Risks and Sustainable Mountain Development: Empirical Evidence from the Karakoram Valleys of Pakistan. Sustainability, 12, 9737. https://doi.org/10.3390/su12229737

WCST (2010). A Socioeconomic Study in the Ngerengere Catchment Area in Morogoro, Uluguru Mountains Payment for Watershed Services Project: Enabling Communities to Benefit from the Sustainable Management of the Ulugurus (75 p.). Morogoro: Wildlife Conservation Society of Tanzania (WCST).

William, C. (2010). Ecology, Conservation and Climate-Fire Challenges on Uluguru Mountain Biodiversity Hotspot, Tanzania (178 p.). Ph.D Thesis, Minneapolis, MN: University of Minnesota.

Yanda, P. Z., \& Munishi, P. K. T. (2007). Hydrologic and Land Use/Cover Change Analysis for the Ruvu River (Uluguru) and Sigi River (East Usambara) Watersheds (80 p.). Dar es Salaam: WWF/CARE. https://citeseerx.ist.psu.edu/viewdoc/download?doi=10.1.1.575.2361\&rep=rep1\&type= pdf

Yitzhaki, S. (1991). Calculating Jackknife Variance Estimators for Parameters of the Gini Method. Journal of Business and Economic Statistics, 9, 235-239. https://doi.org/10.1080/07350015.1991.10509849

Zhang, Y., Liu, L., Liu, Y., Man, Z., \& Cheng-bang, A. (2021). Response of Altitudinal Vegetation Belts of the Tianshan Mountains in Northwestern China to Climate Change during 1989-2015. Scientific Report, 11, Article No. 4870.

https://doi.org/10.1080/07350015.1991.10509849 


\section{Appendix}

Appendix 1. Household income percentiles disaggregated by gender of household, access to extension, and membership to SACCOS/VICOBA.

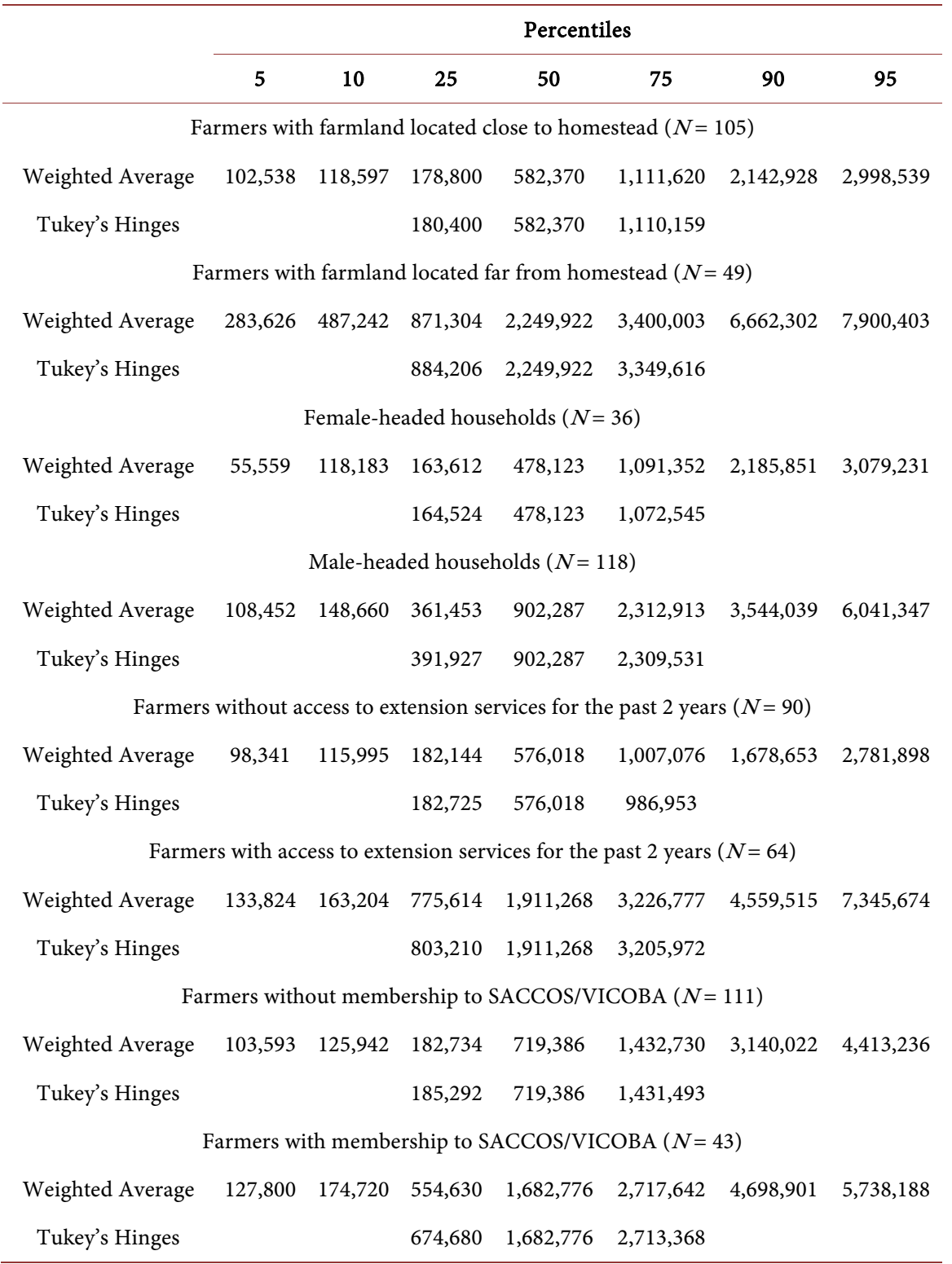

Appendix 2. Results of income inequality disaggregated by gender of household head, access to extension, and membership to SACCOS/VICOBA.

\begin{tabular}{ccccc}
\hline Parameter & Crop income & TPs income & Non-farm income & Total income \\
\hline \multicolumn{5}{r}{ Farmers with farmland located close to homestead $(N=105)$} \\
$\mu_{1}$ & $69,145,476.00$ & $12,180,004.00$ & $11,326,654.50$ & $92,652,134.50$ \\
$W_{i}=\left(\mu_{i} / \mu\right)$ & 0.75 & 0.13 & 0.12 & \\
$\operatorname{Corr}\left(\rho_{i}\right)=\operatorname{correl}\left(y_{i} y\right)$ & 0.99 & 0.95 & 0.38 & $1,022,601.42$ \\
$\operatorname{Sdev}\left(\sigma_{i}\right)$ & $827,929.85$ & $162,103.24$ & $131,328.28$ &
\end{tabular}




\section{Continued}

\begin{tabular}{|c|c|c|c|c|}
\hline$c_{i}=\rho_{i} *\left(\sigma_{i} / \mu_{i}\right) /(\sigma / \mu)$ & 1.33 & 0.01 & 0.00 & \\
\hline$w_{i} C_{i}$ & 0.99 & 0.00 & 0.00 & 1.0 \\
\hline \multicolumn{5}{|c|}{ Farmers with farmland located far from homestead $(N=49)$} \\
\hline$\mu_{1}$ & $2,050,415.62$ & $391,056.41$ & $314,050.08$ & $2,755,522.11$ \\
\hline$w_{i}=\left(\mu_{i} / \mu\right)$ & 0.74 & 0.14 & 0.11 & \\
\hline $\operatorname{Corr}\left(\rho_{i}\right)=\operatorname{correl}\left(y_{i} y\right)$ & 0.98 & 0.89 & 0.84 & \\
\hline $\operatorname{Sdev}\left(\sigma_{i}\right)$ & $1,893,450.39$ & $341,635.97$ & $726,514.52$ & $2,775,918.84$ \\
\hline$c_{i}=\rho_{i} *\left(\sigma_{i} / \mu_{i}\right) /(\sigma / \mu)$ & 1.32 & 1.13 & 2.83 & \\
\hline$w_{i} C_{i}$ & 0.98 & 0.16 & 0.32 & 1.0 \\
\hline \multicolumn{5}{|c|}{ Female-headed households $(N=36)$} \\
\hline$\mu_{1}$ & 554995.68 & 99556.33 & 106439.81 & 760991.82 \\
\hline$w_{i}=\left(\mu_{i} / \mu\right)$ & 0.73 & 0.13 & 0.14 & \\
\hline $\operatorname{Corr}\left(\rho_{i}\right)=\operatorname{correl}\left(y_{i} y\right)$ & 0.99 & 0.97 & 0.1 & \\
\hline $\operatorname{Sdev}\left(\sigma_{i}\right)$ & $704,439.47$ & $143,972.59$ & $113,465.73$ & $846,610.65$ \\
\hline$c_{i}=\rho_{i} *\left(\sigma_{i} / \mu_{i}\right) /(\sigma / \mu)$ & 1.40 & 0.0 & 0.0 & \\
\hline$w_{i} c_{i}$ & 0.99 & 0.0 & 0.0 & 1.0 \\
\hline \multicolumn{5}{|c|}{ Male-headed households $(N=118)$} \\
\hline$\mu_{1}$ & $1,268,101.67$ & $235,235.08$ & $193,926.06$ & $1,697,262.82$ \\
\hline$W_{i}=\left(\mu_{i} / \mu\right)$ & 0.75 & 0.14 & 0.11 & \\
\hline $\operatorname{Corr}\left(\rho_{i}\right)=\operatorname{correl}\left(y_{i} y\right)$ & 0.99 & 0.91 & 0.79 & \\
\hline $\operatorname{Sdev}\left(\sigma_{i}\right)$ & $1,537,857.65$ & $286,885.77$ & $488,217.37$ & $2,161,395.44$ \\
\hline$c_{i}=\rho_{i} *\left(\sigma_{i} / \mu_{i}\right) /(\sigma / \mu)$ & 0.94 & 0.88 & 1.55 & \\
\hline$w_{i} c_{i}$ & 0.7 & 0.12 & 0.18 & 1.0 \\
\hline \multicolumn{5}{|c|}{ Farmers without access to extension services over the past two years $(N=90)$} \\
\hline$\mu_{1}$ & 642328.4 & 112570.8333 & 102003.6 & 856902.8333 \\
\hline$w_{i}=\left(\mu_{i} / \mu\right)$ & 0.75 & 0.13 & 0.12 & \\
\hline $\operatorname{Corr}\left(\rho_{i}\right)=\operatorname{correl}\left(y_{i} y\right)$ & 0.99 & 0.97 & 0.39 & \\
\hline $\operatorname{Sdev}\left(\sigma_{i}\right)$ & $901,231.62$ & $195,836.76$ & $126,505.64$ & $1,131,852.71$ \\
\hline$c_{i}=\rho_{i} *\left(\sigma_{i} / \mu_{i}\right) /(\sigma / \mu)$ & 1.05 & 1.27 & 0.37 & \\
\hline$w_{i} c_{i}$ & 0.79 & 0.17 & 0.04 & 1.0 \\
\hline \multicolumn{5}{|c|}{ Farmers with access to extension services over the past two years $(N=64)$} \\
\hline$\mu_{1}$ & $1,746,973.21$ & $331,412.39$ & $273,981.01$ & $2,352,366.61$ \\
\hline$w_{i}=\left(\mu_{i} / \mu\right)$ & 0.74 & 0.14 & 0.12 & \\
\hline $\operatorname{Corr}\left(\rho_{i}\right)=\operatorname{correl}\left(y_{i} y\right)$ & 0.98 & 0.9 & 0.84 & \\
\hline $\operatorname{Sdev}\left(\sigma_{i}\right)$ & $1,737,420.01$ & $299,687.09$ & $642,648.96$ & $2,514,033.29$ \\
\hline$c_{i}=\rho_{i} *\left(\sigma_{i} / \mu_{i}\right) /(\sigma / \mu)$ & 0.91 & 0.76 & 1.83 & \\
\hline$W_{i} c_{i}$ & 0.68 & 0.11 & 0.21 & 1.0 \\
\hline
\end{tabular}




\section{Continued}

\begin{tabular}{|c|c|c|c|c|}
\hline \multicolumn{5}{|c|}{ Farmers without membership to SACCOS/VICOBA $(N=111)$} \\
\hline$\mu_{1}$ & $952,635.81$ & $171,474.97$ & $161,863.44$ & $1,285,974.22$ \\
\hline$w_{i}=\left(\mu_{i} / \mu\right)$ & 0.74 & 0.13 & 0.13 & \\
\hline $\operatorname{Corr}\left(\rho_{i}\right)=\operatorname{correl}\left(y_{i} y\right)$ & 0.99 & 0.92 & 0.8 & \\
\hline $\operatorname{Sdev}\left(\sigma_{i}\right)$ & $1,442,153.21$ & $254,444.49$ & $481,132.14$ & $2,042,176.98$ \\
\hline$c_{i}=\rho_{i} *\left(\sigma_{i} / \mu_{i}\right) /(\sigma / \mu)$ & 0.94 & 0.86 & 1.51 & \\
\hline$w_{i} c_{i}$ & 0.7 & 0.11 & 0.19 & 1.0 \\
\hline \multicolumn{5}{|c|}{ Farmers with membership to SACCOS/VICOBA $(N=43)$} \\
\hline$\mu_{1}$ & $1,485,424.81$ & $286,233.63$ & $203,448.07$ & $1,975,106.51$ \\
\hline$w_{i}=\left(\mu_{i} / \mu\right)$ & 0.75 & 0.14 & 0.1 & \\
\hline $\operatorname{Corr}\left(\rho_{i}\right)=\operatorname{correl}\left(y_{i} y\right)$ & 0.98 & 0.95 & 0.61 & \\
\hline $\operatorname{Sdev}\left(\sigma_{i}\right)$ & $1,295,822.80$ & $281,703.59$ & $268,688.04$ & $1,706,954.24$ \\
\hline$c_{i}=\rho_{i} *\left(\sigma_{i} / \mu_{i}\right) /(\sigma / \mu)$ & 0.99 & 1.08 & 0.94 & \\
\hline$w_{i} c_{i}$ & 0.75 & 0.16 & 0.1 & 1.0 \\
\hline
\end{tabular}

$\mu_{i}, \mu=$ Mean income for $i$-th source and for total income; $w_{i}=\left(\mu_{i} / \mu\right)=$ Ratio of mean income from $i$-th source to total mean income; $\operatorname{Corr}\left(\rho_{i}\right)=$ Correlation coefficient of $i$-th source and total income; $\operatorname{Sdev}\left(\sigma_{i}\right)=$ Covariance involving the $i$-th source of income; $c_{i}=$ Relative concentration of $i$-th source of income in overall inequality; $w_{i} c_{i}=$ Factor inequality weight of $i$-th source of income in overall inequality

Appendix 3. Coefficients of independent multiple regression models.

\begin{tabular}{|c|c|c|c|c|c|}
\hline \multirow{2}{*}{ Predictors } & \multicolumn{2}{|c|}{ Unstandardized Coefficients } & \multirow{2}{*}{$\begin{array}{c}\text { Standardized Coefficients } \\
\text { Beta }\end{array}$} & \multirow{2}{*}{$\mathbf{t}$} & \multirow{2}{*}{ Sig. } \\
\hline & B & Std. Error & & & \\
\hline \multicolumn{6}{|c|}{ Farmland Located Close to Homestead Coefficients $(N=105)^{\star}$} \\
\hline (Constant) & $-514,367.565$ & $227,484.178$ & & -2.261 & 0.026 \\
\hline$A H H$ (years) & $10,848.024$ & 5648.014 & 0.143 & 1.921 & 0.058 \\
\hline$H H S$ & $-13,495.205$ & $33,054.4$ & -0.031 & -0.408 & 0.684 \\
\hline SFL (acres) & $90,008.578$ & $46,621.945$ & 0.129 & 1.931 & 0.056 \\
\hline$V H A(\mathrm{TZS})$ & 0.127 & 0.012 & 0.732 & 10.834 & 0.000 \\
\hline \multicolumn{6}{|c|}{ Farmland located far from homestead Coefficients $(N=49)^{\star}$} \\
\hline (Constant) & $-4,607,047.607$ & $1,216,775.668$ & & -3.786 & 0.000 \\
\hline$A H H$ (years) & $115,959.309$ & $24,155.536$ & 0.635 & 4.801 & 0.000 \\
\hline HHS & $-420,853.603$ & $111,078.017$ & -0.478 & -3.789 & 0.000 \\
\hline$S F L$ (acres) & $401,363.274$ & $148,280.435$ & 0.255 & 2.707 & 0.010 \\
\hline$V H A(\mathrm{TZS})$ & 0.114 & 0.026 & 0.476 & 4.361 & 0.000 \\
\hline \multicolumn{6}{|c|}{ Female headed households $(N=36)^{\star}$} \\
\hline (Constant) & $-720,370.441$ & $359,887.871$ & & -2.002 & 0.054 \\
\hline$A H H$ (years) & $19,541.823$ & $11,387.503$ & 0.283 & 1.716 & 0.096 \\
\hline$H H S$ & $-20,278.312$ & $66,257.596$ & -0.049 & -0.306 & 0.762 \\
\hline
\end{tabular}




\begin{tabular}{cccccc}
\hline SFL (acres) & $-12,747.086$ & $66,879.772$ & -0.024 & -0.191 & 0.850 \\
$V H A(\mathrm{TZS})$ & 0.125 & 0.022 & 0.755 & 5.760 & 0.000 \\
& \multicolumn{2}{c}{ Male headed households $(N=118)^{*}$} \\
(Constant) & $-1,937,485.378$ & $472,314.517$ & & \\
AHH (years) & $51,423.763$ & $11,184.583$ & 0.347 & 4.598 & 0.000 \\
HHS & $-198,002.550$ & $58,655.420$ & -0.254 & -3.376 & 0.001 \\
SFL (acres) & $248,508.926$ & $64,859.026$ & 0.253 & 3.832 & 0.000 \\
$V H A$ (TZS) & 0.130 & 0.016 & 0.583 & 8.254 & 0.000
\end{tabular}

Farmers without access to extension over the past two years $(N=90)^{*}$

$\begin{array}{cccccc}\text { (Constant) } & -557,865.662 & 300,840.561 & & -1.854 & 0.067 \\ \text { AHH (years) } & 26,163.083 & 7234.497 & 0.288 & 3.616 & 0.001 \\ H H S & -164,293.575 & 37,156.247 & -0.360 & -4.422 & 0.000 \\ \text { SFL (acres) } & 100,782.514 & 40,329.021 & 0.172 & 2.499 & 0.014 \\ \text { VHA (TZS) } & 0.126 & 0.012 & 0.738 & 10.655 & 0.000\end{array}$

Farmers with access to extension over the past two years $(N=64)^{*}$

$\begin{array}{cccccc}\text { (Constant) } & -2,604,921.770 & 769,805.687 & & -3.384 & 0.001 \\ \text { AHH (years) } & 61,639.762 & 19,010.114 & 0.391 & 3.242 & 0.002 \\ H H S & -181,626.316 & 105,110.216 & -0.201 & -1.728 & 0.089 \\ \text { SFL (acres) } & 318,707.189 & 113,497.797 & 0.274 & 2.808 & 0.007 \\ V H A \text { (TZS) } & 0.115 & 0.028 & 0.452 & 4.194 & 0.000\end{array}$

Farmers without membership to SACCOS/VICOBA $(N=111)^{*}$

$\begin{array}{cccccc}\text { (Constant) } & -1,619,612.513 & 398,075.004 & & -4.069 & 0.000 \\ \text { AHH (years) } & 37,626.584 & 9735.760 & 0.275 & 3.865 & 0.000 \\ H H S & -92,796.971 & 54,718.207 & -0.118 & -1.696 & 0.093 \\ \text { SFL (acres) } & 132,868.757 & 66,452.625 & 0.121 & 1.999 & 0.048 \\ V H A \text { (TZS) } & 0.154 & 0.014 & 0.696 & 10.666 & 0.000\end{array}$

Farmers with membership to SACCOS/VICOBA $(N=43)^{*}$

\begin{tabular}{cccccc} 
(Constant) & $-4,607,047.607$ & $1,216,775.668$ & & -3.786 & 0.000 \\
AHH (years) & $115,959.309$ & $24,155.536$ & 0.635 & 4.801 & 0.000 \\
$H H S$ & $-420,853.603$ & $111,078.017$ & -0.478 & -3.789 & 0.000 \\
SFL (acres) & $401,363.274$ & $148,280.435$ & 0.255 & 2.707 & 0.010 \\
$V H A$ (TZS) & 0.114 & 0.026 & 0.476 & 4.361 & 0.000 \\
\hline
\end{tabular}

*Dependent Variable: Total household income (TZ). 